\title{
Türkçedeki Yan Cümlelerde Öznenin İfade Ediliş Biçimleri
}

\author{
Dr. Öğr. Üyesi Özlem Erdoğan \\ Sivas Cumhuriyet Üniversitesi, Edebiyat Fakültesi \\ Türk Dili ve Edebiyatı Bölümü \\ oerdogan@cumhuriyet.edu.tr
}

$\ddot{O} z$

Türkçede özne, nesne, dolaylı tümleç ve zarf tümleci gibi cümleye mahsus ögeler, yüklem görevindeki bir çekimli fiil yerine bir fiilimsiye de bağlanabilir ve böylece, dizimsel kurgusu itibarıyla cümleye benzeyen ancak yükleminin çekimsiz olması nedeniyle bir cümle gibi bağımsız bir şekilde kullanılamayan yan cümleler ortaya çıkar. Yan cümlelerin bağımsız kullanılamaması, bu yapıların her zaman ya bir cümle ya da bir sözcük öbeği olmak üzere başka bir dizimin kurgusuna katılmasını ve o dizime ait bir unsuru oluşturmasını gerektirir. Burada yönetici öge -yani, yüklem- olarak öne çıkan fiilimsiler, kendi etrafında oluşturduğu cümlesel yapının başka bir dizimin içinde kolaylıkla yer alabilmesini sağlar. Bu tür bir yükleme bağlanan özne, nesne ve tümleç gibi ögelerin durumu incelendiğinde öncelikle bu ögelerin yan cümledeki kullanımının herhangi bir cümledeki kullanımılla tamamen eş değer olduğu görülür. Bunun yanında, bir kısım örneklerde de söz konusu ögelerle ilgili sadece yan cümleye özgü birtakım kullanım biçimleri sistemli bir şekilde kendini gösterebilir. Bu tür örneklerde ise ögenin çoğu kez yan cümlenin üst dizimdeki cümle veya sözcük öbeğiyle bütünleşmesi noktasında önemli roller üstlendiği gözlemlenir. $\mathrm{Bu}$ çalışmada, söz konusu ögelerden özne ele alınmıştır. Bu çerçevede, öznenin ne tür örneklerde yan cümlenin içinde yer alarak fiilimsiye bağlanabileceği ve yan cümlede bir öznenin bulunmaması durumunda bu ögeyle verilen ve anlamın tamamlanması için de ihtiyaç duyulan bilginin başka hangi yollarla sağlanabileceği üzerinde durulmuştur. Ayrıca, yan cümlenin parçası olduğu üst dizimle kurması muhtemel anlamsal ve yapısal bağıntıların oluşmasında öznenin nasıl bir rolünün olduğu sorgulanmıştır.

Anahtar Kelimeler: Türkçe, yan cümle, dizim, özne, fiilimsi.

\section{The Expression Types of the Subject in Turkish Subordinate Clauses}

\footnotetext{
Abstract

In Turkish, elements of sentence such as the subject, object or complement can also connect to nonfinite verbs instead of finite verbs as predicate. In this way, "subordinate clauses", which are similar to sentence in terms of syntagm but couldn't be used independently like sentence because of the nonfinite verb, are formed. Not being able to use these structures independently requires that they take place as an element in another syntagm, either sentence or word group. Here, the nonfinitive verbs coming forward as the governer element -that is, predicate- enable the syntagmatic structure formed around itself to take place in another syntagm easily. When the sentence elements connected to this kind 
of predicate are examined, firstly it's seen that they're used in the subordinate clause just as being used in a sentence. Furthermore, in some examples, it can also be observed that they're used systematically in a way peculiar to subordinate clauses. In such examples, they often have important roles in the integration with the upper syntax. In this paper, the subject, which is one of these elements, has been discussed. In this context, it has been investigated when the subject can take place in subordinate clauses and if there isn't a subject in subordinate clauses, how the information given by the subject and which is necessary to complete the meaning is obtained. Furthermore, the roles which the subject can assume in probable structural and semantic connections occuring between the subordinate clause and upper syntagm containing itself have been questioned.

Keywords: Turkish, subordinate clauses, syntax, subject, nonfinite verbs. 


\section{GíRIŞ}

Türkçede bir cümle bir başka cümlenin içinde yer alabilir ve bu oluşum, şu iki farklı şekilde gerçekleşir:

1. Cümle, temel cümlesel özelliklerini muhafaza ederek başka bir cümlenin bünyesinde yer alır. Söz gelimi, "Necile aklımı oynattım zannetme." (Peyami Safa, 2008, s. 327) örneğinde "Aklımı oynattım." cümlesi bu yolla bir başka cümlenin kurgusuna katılmıştır. Bu tür cümleler, "iç cümle" olarak adlandırılmaktadır. ${ }^{1}$

2. Cümle, başka bir cümlenin kurgusuna katılırken bir fiilimsi veya fiilimsi öbeğine dönüşür. Söz gelimi, yukarıdaki örneğin "Necile aklımı oynattığımı zannetme." şeklinde olması durumunda "Aklımı oynattım." cümlesi bu kez bir sıfat-fiil öbeğine dönüşmüş olarak karşımıza çıkar. Bir fiilimsi veya fiilimsi öbeği niteliği gösteren bu yapılar ise çeşitli kaynaklarda "yan cümle" olarak veya benzer terimlerle ele alınmaktadır. ${ }^{2}$

Burada dikkat çeken başlıca husus, iç cümlelerin başlı başına bir cümle olma özelliğini göstermesine karşılık yan cümlelerde bir açıdan cümleyle ortak, bir açıdan da cümleden ayrı özellikler gösteren farklı bir yapının ortaya çıkmış olmasıdır.

Buna göre, yan cümle ile cümle arasındaki ortak nokta olarak her ikisinin de aynı dizimsel değere sahip oluşu gösterilebilir. Söz gelimi, "Kafesin arasından bir duman gibi sızdı." cümlesine bakıldığında burada sırasıyla "Dolaylı Tümleç-Zarf Tümleci-Yüklem" ögelerinden oluşan bir dizim görülmektedir ve bu dizim, cümle "Kafesin arasından bir duman gibi sızarak dolunaya doğru uçtu." (Anar, 2006, s. 47-48) örneğindeki gibi bir zarffiil öbeğine dönüştürüldüğünde de yine varlığını sürdürmektedir. Bir başka ifadeyle, bu örnekte de "Yan Cümlede Dolaylı Tümleç-Yan Cümlede Zarf Tümleci-Yan Cümlede Yüklem" şeklinde bir dizim karşımıza çıkmaktadır. Bu da buradaki "sızarak" şeklindeki zarf-fiilin sadece bir sözcük olmanın ötesinde çeşitli cümle ögelerini yönetebilme erkine de sahip bir unsur olduğunu göstermektedir. Benzer şekilde, fiilimsi öbeklerinin de sadece bir sözcük öbeği değil, aynı zamanda kendi içinde cümlesel özellikler gösteren yapılar olduğunu ortaya koymaktadır. Cümleye özgü ögelerin tüm sözcük öbekleri arasında yalnızca fiilimsi öbeklerinin bünyesinde yer alabiliyor olması da bu öbeklerin cümleyle kesişen bir yönünün olduğunu ayrıca desteklemektedir.

Bir yan cümlenin cümleden ayrılan yönünü ise -yukarıdaki örneklerde de görüldüğü gibi- kip ve şahıs ekleriyle çekimlenmiş bir yükleme sahip olmaması ve buna bağlı olarak da bir cümle gibi bağımsız bir şekilde kullanılamaması özellikleri oluşturmaktadır. ${ }^{3}$ Bu durum,

\footnotetext{
1 bkz. (Topaloğlu, 1989, s. 85; Korkmaz, 2007a, s. 121; Delice, 2007, s. 166; Aktan, 2009, s. 132; Özkan \& Sevinçli, 2011, s. 201; Özmen, 2013, s. 179). Ayrıca, (Hatiboğlu, 1972, s. 152-153; Dizdaroğlu, 1976, s. 192; Sağlam, 1977, s. 103-104; Şimşek, 1987, s. 277; Koç, 1990, s. 456; Bilgin, 2002, s. 532)'de "içtümce” ve (Bozkurt, 2010, s. 130)'da “iç tümce”.

2 (Emre, 1945, s. 504)'te "yanal cümle", (Üçok, 1947, s. 106)'da "yansıralama"; (Bilgegil, 1963, s. 73-74; Ediskun, 1963, s. 379; Toparlı, Karataş \& Vural, 1995, s. 111)'de "yan cümlecik"; (Banguoğlu, 1974, s. 547-548)'de "yancümle veya alt cümle", (Kükey, 1975, s. 264)'de "yan tümcecik"; (Hatiboğlu, 1972, s. 180; Dizdaroğlu, 1976, s. 191-192; Sağlam, 1977, s. 193; Atabay, Özel \& Çam, 1981, s. 109; Koç, 1990, s. 444)'te "tümcemsi"; (Gencan, 1966, s. 88)'de "yan veya bağınlı önerme"; (Burdurlu, 1967, s. 96-97)'de "yan yarg1", (Şimşek, 1987, s. 251)'de "yantümcecik veya tümcemsi", (Demir \& Yılmaz, 2003, s. 213; Delice, 2007, s. 163-165; Daşdemir, 2014, s. 176-179)'da "yan cümle"; (Erkul, 2007, s. 61)'de "yan cümle veya cümlecik"; (Erkman Akerson \& Ozil 1998, s. 60; Bilgin, 2002, s. 511; Aksan, 2005, s. 123$124)$ 'te "yan tümce" ve (Uzun, 2000, s. 40)'ta "yerleşmiş tümce".

$3 \mathrm{Bu}$ özellik, bir yargı bildirmediği gerekçesiyle fiilimsi ve fiilimsi öbeklerinin yan cümle olarak değerlendirilemeyeceği yönünde tamamen karşıt bir yaklaşımı da beraberinde getirmiştir (Mansuroğlu, 1955, s. 59; Ergin, 1962, s. 316; Topaloğlu, 1989, s. 158; Karahan, 1994a, s. 21-22; Zülfikar, 1995, s. 648; Korkmaz, 1997, s. 53; SEFAD, 2020; (43): 195-220
} 
yan cümlelerin her zaman ya bir cümlenin ya da bir sözcük öbeğinin içinde yer almasını gerektirir. Buna göre, bir cümlenin içinde yer almışsa cümle ögelerinden birini oluşturan yan cümleler, bir sözcük öbeğinin içinde bulunması durumunda da öbeği meydana getiren unsurlardan birini temsil eder. Söz gelimi, "Onun için sana her şeyi anlatmak istiyorum." (Peyami Safa, 2008, s. 297) örneğinde cümlenin nesnesi; "çantasından mendilini almak / bahanesi" (Peyami Safa, 2008, s. 145) örneğinde ise belirtisiz isim tamlamasının tamlayanı olarak bulunan isim-fiille kurulu yan cümle örnekleri görülmektedir. Burada ikinci örnekteki belirtisiz isim tamlamasının da bir cümlenin parçası olabileceği göz önünde bulundurulursa yan cümlelerin bu tür örneklerde içinde yer aldığı sözcük öbeği aracılığıyla cümleye katıldığı da düşünülebilir. Sonuçta ise cümleye ister doğrudan bir cümle ögesi olarak isterse bir sözcük öbeğinin içinde yer alarak katılmış olsun yan cümlelerin her örnekte parçası olduğu üst dizimle bütünleşmiş bir durumda olduğunu belirtmek mümkündür. Bu bütünleşmeden dolayı içinde söz konusu yapıları bulunduran cümleler de bir "girişik-birleşik" cümle örneği oluşturur.

Özetlemek gerekirse yan cümleler iki cümlenin birleştirilerek tek bir cümle hâlinde ifade edilmek istenmesi durumunda, cümlelerden birinin diğer cümlenin içinde yer almak üzere bir fiilimsi veya fiilimsi öbeğine dönüşmesi sonucu ortaya çıan yapılar olarak tanımlanabililir. Cümlenin içinde yer alması, ya doğrudan bir cümle ögesi olmasıyla ya da cümlede görevli bir sözcük öbeğinin içinde bulunması yoluyla gerçekleşen bu yapıların temel özellikleri, "yönetici ögesinin çekimsiz bir fiilden oluşması", "dizimsel özellikleri bakımından cümleye benzemesi" ve "bir cümle gibi bağımsız bir şekilde kullanılamaması" şeklinde sıralanabilir. Buna göre, tüm fiilimsi ve fiilimsi öbekleri, aynı zamanda bir yan cümleyi temsil etmektedir. ${ }^{4}$ Bu noktada, kullanılan fiilimsi ekinin türü de göz önünde bulundurulursa "isim-fiille kurulan yan cümleler", "sifat-fiille kurulan yan cümleler" ve

Turan, 1999, s. 306; Savran, 1999, s. 329; Karahan, 2000, s. 18-19; Cemiloğlu, 2001, s. 66; Özkan \& Sevinçli, 2011, s. 207-208; Karaörs, 2005, s. 160-1611; Mehmedoğlu, 2005, s. 95; Aktan, 2009, s. 129-130; Deniz Yılmaz, 2009, s. 37-38; Üstünova, 2010, s. 700; Özmen, 2013, s. 144; Özkan, Toker \& Aşçı 2016, s. 128-129; Kültüral, 2018, s. 34; Böler, 2019, s. 215). Bu çalışmalarda temel olarak kip ve şahıs ekleriyle çekimlenmiş bir fiilin yüklem olmadığı yapılarda bir yargıdan söz edilemeyeceği ve yargı ifade etmeyen bir yapının da cümlesel bir değer taşıyamayacağı tezi öne çıkar. $\mathrm{Bu}$ tez doğrultusunda da fiilimsiler sadece bir sözcük; fiilimsi öbekleri de sadece bir sözcük öbeği olarak değerlendirilir. Diğer taraftan, burada temel ölçüt olarak karşımıza çıkan "yargı" kavramının ne olduğu da tartışılagelen konulardan biridir. Bu konuyla ilgili olarak Uzun, "Ali tam Amerika'ya gidecekti." örneğini vermiş ve bu cümlede 'Eee, n'oldu?' diye sormayı gerektiren bir eksiklik olduğuna -bir anlamda, yargiyla cümleyi eşitleyen kabulün her zaman ve her örnekte geçerli olmayabileceğine- dikkat çekmiştir (1998, s. 64). Karabulut, Türkiye'de tüm cümle tanımlarının "yargı" kavramı etrafında yapılmasına rağmen yargının ne olduğu hakkında bir tanımın yapılmadığını belirtmiş (2009a, s. 275) ve bu kavramın anlamla ilgili olduğunu, bu nedenle sadece cümlenin değil, anlamı olan her sözcük ve sözcük öbeğinin de bir yargı içerdiğini, söz gelimi "yeşil" sözcüğünün bir renk hakkında verilen hükmü ifade ettiğini dile getirmiştir (2009, s. 276-277). Benzer bir şekilde, Delice de "kot pantolonlu çocuk" öbeğinin "Çocuk kot pantolonu giymiş." yargısını bildirdiğini ve dolayısıyla, yargının sadece cümleye has bir kavram olmadığını belirtmiştir (2012, s.38). Bu görüşler, konuyla ilgili yargı temelli değerlendirmelere alternatif bir yaklaşım olarak görülebilir. Zira, fiilimsi ve fiilimsi öbeklerinin yarg1 bildirip bildiremeyeceği konusu bu doğrultuda tekrar ele alındığında bu yapıların da bir yargı bildirdiği ancak yargı "anlam" ile ilgili olduğu için bu kavramın herhangi bir yapıyı tanımlamakta tek başına yeterli olmadığı sonucu ortaya çıkmaktadır.

${ }^{4}$ Hangi unsurların yan cümle oluşturabileceği konusunda kaynaklarda esasında bir görüş birliği yoktur. Çeşitli kaynaklarda fiilimsiler dişında ki, dA, yA, değil, gibi, mI vb. daha birçok unsur yan cümle konusuyla ilişkilendirilmekte ve bu unsurların yan cümleyi temel cümleye bağladığı dile getirilmektedir. Bunun yanında, yan cümlenin kavram olarak ne olduğu hakkında da kaynaklar arasında muazzam farklılıklar görülebilmektedir. Ayrı bir çalışmanın konusu olacak kadar geniş olduğu için burada bu mevzunun ayrıntılarına girilmemiş; bunun yerine "yönetici ögesinin çekimsiz bir fiilden oluşması ve cümle ögelerini yönetebilmesi" ölçütü esas alınarak sadece fiilimsi ve fiilimsi öbeklerinin yan cümle oluşturabileceği görüşüne yer verilmiştir. Yan cümleler de kavram olarak bir cümlenin başka bir cümleye bağlanmasıyla değil, bir cümlenin başka bir cümlenin içinde yer almasıyla ortaya çıkan yapılar olarak ele alınmıştır. 
"zarf-fiille kurulan yan cümleler" ile yine fiilimsi eki olarak ele aldığımız şart işlevli -sA ekinin kullanıldığı "şart-fiille ${ }^{5}$ kurulan yan cümleler" olmak üzere dört farklı yan cümle türünden söz edilebilir.

Bu genel çerçeve kapsamında bir yan cümlenin bünyesinde yer alabilecek özne, nesne, dolaylı tümleç ve zarf tümleci gibi yüklemi tamamlayan ögeler incelendiğinde öncelikle yukarıda sözü edilen yan cümle ile cümle arasındaki dizimsel benzerliğin bir sonucu olarak bu ögelerin tıpkı cümledeki gibi kullanıldığı görülür. Bu kullanım biçiminde öge, yan cümle yüklemine hem yapısal hem de anlamsal olarak bağlıdır. Bunun dışında, yan cümle ögesinin cümledeki kullanımından farklı olarak yüklemle arasındaki yapısal bağlllı̆̆ yitirirken anlamsal bağını koruduğu başka türlü kullanım biçimleri de mevcuttur. Bu kullanım biçimleri, temel olarak bir ögenin yan cümlenin yapısal sınırlarından eksiltilerek üst dizime ait belli bir konuma getirilmesi şeklinde işlemektedir. Söz gelimi, "\{Aşevinde yere düşürülen / bir bakır\} sesiyle irkildi." (Kemal Tahir, 1993, s. 16) cümlesinde "aşevinde yere düşürülen" şeklinde bir yan cümle görülmektedir. Yere düşürülen şeyin ne olduğu hakkındaki bilgi ise bu yan cümlenin yapısal sınırları içinde bulunmamaktadır. Bu bilgi, ancak yan cümlenin parçası olduğu sıfat tamlamasında nitelendirilen ismin konumuna taşınmış olan "bir bakır" unsuruyla tamamlanabilmektedir.

Yan cümle ögeleri, gerek cümledeki gibi yüklemi yapı ve anlam bakımından tamamlıyor olsun gerekse yukarıdaki örnekte olduğu gibi yan cümlenin yapısal sınırları içinde bulunmadığı hâlde yüklemle anlamsal bağını sürdürüyor olsun yan cümlelerin temel oluşum ve kullanım özellikleri hakkında bilgi vermesi bakımından oldukça önemlidir. Zira, söz konusu ögeler incelendiğinde derin yapıdaki anlamın bir yan cümle şeklinde yüzeysel yapıya aktarılmasında birtakım yapıların "sistemli bir şekilde" kullanıldığı dikkat çekmektedir. Bu çalışmada, bu yapıların neler olduğu özne çerçevesinde ele alınmış ve "özne ögesiyle ifade edilen bilginin" bir yan cümlede hangi yollarla ortaya konabileceği tespit edilmeye çalışılmıştır. Buna göre, yan cümlelerde özneyi veya özneyle verilen bilgiyi belirtmek için şu yollardan birine başvurulduğu ifade edilebilir:

\section{YAN CÜMLEDE ÖZNE}

Özne, kılış fiillerinin yüklem olduğu cümlelerde eylemi gerçekleştiren kişi veya şeydir. ${ }^{6}$ Buna göre, bir cümlede özne ögesiyle ifade edilen bilgi de eylemin gerçekleştiricisiyle ilgili olmalı ve faile işaret etmelidir.

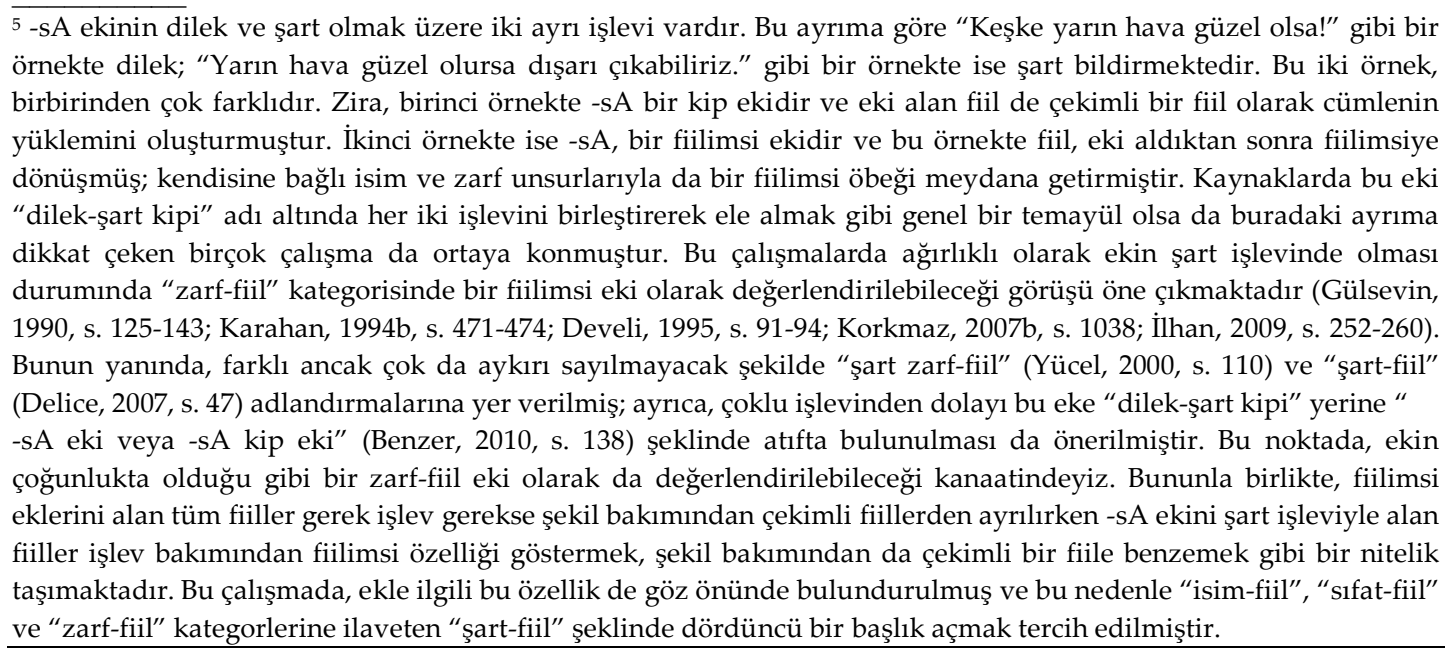
SEFAD, 2020; (43): 195-220 
Bu bağlamda, cümlede yüklemi tamamlayan özne, yan cümlede de aynı şekilde yan

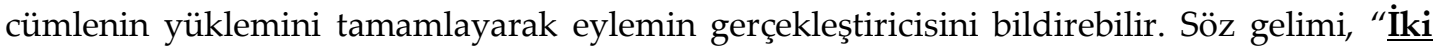
adam gelince nasıl konuşulur, nasıl oturulur, nasıl kalkılır?" (Baykurt, 2013, s. 191) örneğine bakıldığında "iki adam" ögesinin özne göreviyle "gelince" şeklindeki yan cümle yüklemine bağlı olduğu ve böylece, gelme eylemini kimin gerçekleştirdiğini ortaya koyduğu görülmektedir. Benzer bir şekilde, "Şakir Efendi çıkıp gittikten sonra Aşağı Mahalle'den Fatma geldi." (Baykurt, 2013, s. 223) örneğinde de "Şakir Efendi" ögesi, yan cümlenin yüklemine bağlı bir özne olarak karşımıza çıkmaktadır. Çekimsiz bir öge olan öznenin bu örneklerdeki kullanımının cümledeki kullanımından farksız olduğu ifade edilebilir.

Yan cümlede özne isim-fiil, sıfat-fiil, zarf-fiil ve şart-fiil ekleriyle kurulanlar olmak üzere tüm yan cümle türlerinde görülebilmektedir. Örneklerin önemli bir kısmında yan cümlenin ya zaman ilgisi kuran bir çekim edatıyla bir araya gelerek çekim edatı öbeği oluşturduğu ya da cümlenin kurgusuna çoğu kez zaman ifade eden bir zarf tümleci olarak doğrudan katıldığı gözlemlenir. Bunun yanında, daha farklı yapı ve işlevlerle kullanılan örneklerle de karşılaşmak mümkündür. Bu bağlamda, yan cümlenin türüne göre karşımıza en sık çıabilecek örnekleri şu şekilde ele alabiliriz:

İlk olarak, isim-fiille kurulu yan cümle türünde öznenin kullanımıla ilgili olarak daha çok yan cümlenin bir cümle yerine bir çekim edatı öbeğinin kurgusuna katıldığı kullanım biçimi öne çıkar. Buna göre, çekim edatı öbeğinin birinci kısmında isim değerinde bir yan cümle ve ikinci kısmında da çekim edatı öbeklerinin yapısı gereği bir çekim edatı bulunur. Buradaki yan cümle aşağıdaki örneklerde de görüldüğü gibi çoğu kez -mA isim-fiil ekiyle kurulur ve çoğunlukla da -DAn önce veya muadili bir çekim edatıyla birlikte kullanılır:

"\{Mustafa Efendi leylî meccanî imtihanına girme /den önce\} de, [babası] 'Aman oğlum boşuna zahmet etme; bu işler iltimassız olmaz,' demişti." (Atay, 2013, s. 43)

“\{ Aristo Eski Yunan'da bilimin temellerini atma / dan önce\} mitoloji yürürlükteydi." (Atay, 2013, s. 76)

Aynı yapı, bazı işlevsel farklılıklarla sıfat-fiille kurulu yan cümlelerde de görülür. Burada da bir özne ihtiva eden sıfat-fiille kurulu yan cümle çekim edatı öbeğinin birinci birleşenini oluşturur. Bu yan cümle çoğunlukla ya -An ya da -DIk sıfat-fiil ekiyle kurulmuştur. Aşağıdaki örneklerde de görüleceği üzere eğer -An ekiyle kurulmuşsa çekim

\footnotetext{
${ }^{6}$ Burada özneyi "kılanı ve olanı karşılayan öge" şeklinde ele alan yaygın görüşten farklı olarak "sadece kılanı karşılayan öge" olarak sınırlandırmak tercih edilmiştir. Kaynak olarak (Delice, 2004, s. 127-169)'a dayanan bu tercihin gerekçesi, ilgili kaynak doğrultusunda şöyle açılanabilir: Bir cümle, ya bir kılış ya bir oluş ya da bir durum olmak üzere üç farklı gerçekliği yansıtabilir. Buna bağlı olarak da yüklemi bir kılış fiilinden oluşan "kılış cümleleri"; yüklemi bir oluş fiilinden oluşan "oluş cümleleri" ve yüklemi ek-fiil almış bir isimden oluşan "durum cümleleri" ortaya çıkar. Burada oluş cümlelerleri, yansıttığı gerçeklik itibarıyla kılış sonrasını; durum cümleleri ise kılış ve oluş sonrasındaki hâli ifade eder. Söz gelimi, "Çocuğun yüzü sarardı." gibi bir oluş cümlesinde olma öncesi kılış evresi, "Hastalık çocuğun yüzünü sararttı." şeklinde ifade edilebilir. Burada dikkat çeken temel husus, kılış evresinde kılışın gerçekleştiricisini bildiren unsurun anlatım oluş veya durum evrelerini yansıtır bir hâle getirildiğinde artık belirtilmiyor olmasıdır. Yani, kılış evresini ifade eden cümlede özne olarak tanımlanabilecek "hastalık" ögesi, oluş evresi dile getirildiğinde artık kullanılmamakta ve cümle de bu kez eylem ile nesneyi ifade eden unsurlar temel alınarak oluşturulmaktadır. Bu durumda, "çocuğun yüzü" ögesi, esasında oluş cümlesinde de nesneyi temsil etmektedir ve bu husus, tüm oluş ve durum cümlelerinde benzer bir şekilde geçerlidir. Ayrıca, "Ahmet [ödevlerini] zamanında yapıyor." ve "Hasan [bir takım elbise] satın aldı." gibi örneklerdeki nesne ögesi, yalnızca yüklemi geçişli olan kılış cümlelerinde görülebilir; oluş ve durum cümlelerinde ise yüklem, bu tür bir nesneyi alma erkine sahip değildir (Delice, 2007, s. 157). Bu da kılış cümleleri ile oluş ve durum cümlelerinin birbirinden farklı gerçekliklere yaslanıp farklı anlam, yapı ve kurgu özellikleri gösterdiğini ortaya koyan bir husus olarak görülebilir.
} 
edatı öbeğinin ikinci kısmında çoğunlukla -A kadar; -DIk ekiyle kurulmuşsa da çoğunlukla DAn sonra çekim edatı yer alır:

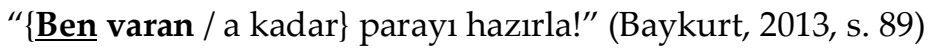

“保aymakam gelen / e kadar\} varıp gelivereyim!" (Baykurt, 2013, s.155)

“\{Köpek sustuk / tan sonra\} da Mefharet epeyce bekledi." (Peyami Safa, 2008, s. 67)

"\{Babası odadan çıktık / tan sonra\} Meral kendini koltuğa attı." (Peyami Safa, 2008, s. 187)

Buna ilaveten, sıfat-fiille kurulan yan cümlelerde öznenin kullanımıyla ilgili olarak bir yapıdan daha söz edilebilir. Bu yapıda öznesi olan sıfat-fiille kurulmuş yan cümle, aşağıdaki örneklerde olduğu gibi bir sıfat tamlamasında sıfat konumundadır:

"Şakir Efendi (...) şimdi de \{yllan sokan / yeri\}i yarıyor." (Baykurt, 2013, s. 269)

“\{Top sökmez / bir karanlık\}, (...) çöktü evin içine." (Baykurt, 2013, s. 263)

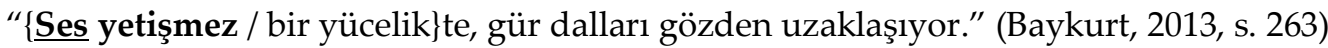

Zarf-fiille kurulmuş olup özne içeren yan cümlelerde ise temel olarak iki tür örnek dikkat çekmektedir. Bunlardan ilki, yine yan cümlenin bir çekim edatı öbeğinin kurgusuna katıldığı yapıdır. Bu örneklerde yan cümlenin aşağıdaki gibi çoğunlukla ya -IncA zarf-fiil ekiyle kurulu olarak -A kadar çekim edatıyla ya da -AlI zarf-fiil ekiyle kurulu olarak beri çekim edatıyla birlikte kullanıldığı görülür:

“(...)\{öğrenciler yatınca / ya kadar\} bir muavin gibi çalışırdı.” (Atay, 2013, s. 42)

"\{Ben gelince / ye kadar\} bir koroner spazmından ansızın ölmüş. (Peyami Safa, 2008, s. 387)

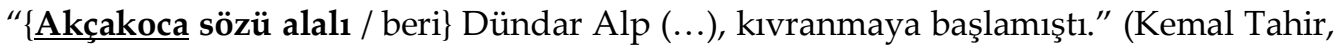
1993, s. 144)

Zarf-fiille kurulu yan cümlelerde öznenin kullanımıla ilgili ikinci tür örnekler ise aslında genel olarak yan cümlede öznenin en sık görüldüğü grubu oluşturmaktadır. $\mathrm{Bu}$ örneklerde -ken, -Inca, -AlI, -mAdAn, -DIkçA, -DIğIndA, -DI mI, -DI -AlI, -Ar -mAz gibi pek çok zarf-fiil ekinden biriyle kurulmuş olan yan cümle, bu kez bir sözcük öbeğinin değil; bir cümlenin kurgusuna katılmıştır ve bu cümle içinde aşağıda olduğu gibi çoğunlukla zaman ifade eden bir zarf tümleci görevindedir:

"Bünyamin hıçkıra hıçkıra gözyaşı dökerken bir ilkbahar yağmuru başlamıştı." (Anar, 2006, s. 111)

"Büyük Efendi örtüyü kaldırınca ortaya akıllara sığmaz bir ayna çıtı." (Anar, 2006, s. 175)

"Fakat ben senin meseleni halledeli yarım saatten fazla olmadı." (Peyami Safa, 2008, s. 128)

"Onlar daha atlarından inmeden konağın kapısı açılmış[tı] (...)." (Anar, 2006, s. 169)

"Yılanlar böyle yaptıkça bize de onları bir bir öldürmek düşüyor." (Baykurt, 2013, s. 36)

"Adamlar aceleyle odadan çıktıklarında Bünyamin yalnız olmadığını hissetti." (Anar, 2006, s. 48)

"Bir toprağa Moğol atı bastı mı, gökten say ki, bela indi." (Kemal Tahir, 1993, s. 48)

SEFAD, 2020; (43): 195-220 
“Biz bildik bileli oturaktır buralar...” (Kemal Tahir, 1993, s. 9)

“Gözcü, atlılar ovadan görünür görünmez işaret versin, davranıp karşı çıkalım!" (Baykurt, 2013, s. 162)

Bunun yanında, yan cümlenin söz konusu örneklerde durum veya neden bildirmek gibi daha farklı işlevlere sahip olduğu şu ve benzeri örneklerle de karşılaşmak mümkündür:

“Bugün artık kimse görmeden çalışamazsın, (...)." (Atay, 2013, s. 263)

"Birazı da, Ertuğrul Bey çapul akınlarını yasakladığından savuştu." (Kemal Tahir, 1993, s. 31)

Özneyi bünyesinde rahatllkla ihtiva edebilen bir diğer yan cümle türü ise şart-fiille kurulu yan cümlelerdir. Bu tür örneklerde yan cümle, aşağıda olduğu gibi bir cümlenin kurgusuna şart bildiren bir zarf tümleci göreviyle katılmış olarak karşımıza çıkar:

“Meral iki kelime daha söylese Ferhat'ı şirketten atabilirlerdi." (Peyami Safa, 2008, s.

"Eğer ağabeyisi anahtarı saklamışsa dışarı çıkmak mümkün değildi." (Peyami Safa, 2008, s. 323)

"Allah'ım, o sana ne kadar iyilik ettiyse sen ona o kadar fenalık ettin." (Peyami Safa, 2008, s. 270)

“Eller hangi sözden konuşuyorsa, sen de o sözden konuşacaksın." (Baykurt, 2013, s. 82)

"Gülletopuk onları bulursa hiç suçu olmadığı halde kendisi de tehlikeye girecekti." (Anar, 2006, s. 32)

Öznenin yan cümlede bulunması durumunda karşımıza en sık çıkabilecek örnekler, bu şekilde sıralanabilir. Bunun yanında, daha farklı örneklere rastlamanın her zaman mümkün olabileceğini de ayrıca belirtmek gerekir.

\section{YAN CÜMLENIN ÖZNESINE ISSARET EDEN UNSURLAR}

Özne, yan cümlenin yapısal sınırları içinde her zaman bulunmaz. Bu durumda, belli bir biçimbirim veya yapı aracıllğıyla bu ögeye işaret edilebilir. Öznenin yan cümlenin türüne ve kullanım şekline göre değişen bu tür ifade ediliş biçimleri de aşağıdaki gibidir:

\subsection{Yan Cümle Yüklemindeki Biçimbirimler ile Bildirilen Özne}

Bilindiği üzere, çekimli fiillerdeki şahıs ekleri, eylemi kimin veya neyin gerçekleştirdiğine -dolayısıyla, özneye- işaret eder. Söz gelimi, "Geldiler." cümlesinde gelme eylemini onların gerçekleştirdiği, -1Ar üçüncü çokluk şahıs ekinden anlaşılmaktadır.

Çekimsiz fiillerle kurulan yan cümlelerde ise yüklem şahıs eki almadığından özneye böyle bir biçimbirim vasıtasıyla işaret edilmesi mümkün olmamaktadır. Bununla birlikte, bu kaidenin dışına çıkan örnekler de mevcuttur.

Bunun bir örneği, -DIğIndA ve -DIğIndAn gibi birden fazla ekin kalıplaşmasıyla ortaya çıkmış zarf-fiillerle kurulu yan cümlelerde görülür. Bu nitelikteki yan cümlelerde zarf-fiil ekini oluşturan kalıplaşmış ekler arasında bulunan iyelik ekleri, aşağıda olduğu gibi yan cümledeki eylemin gerçekleştiricisine işaret eder: 
“[Ben] bilgi tehlike ile ölçülür dediğimde kastettiklerim bunlardı.” (Anar, 2006, s. 135)

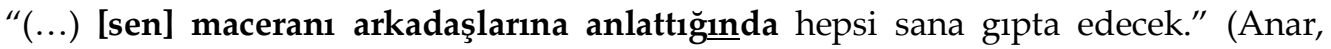
2006, s. 55)

“[O] Ankara'dan döndüğünde Mustafa ile tekrar buluştuk." (Atay, 2013, s. 226)

"[Biz] Sırtımızda yatak taşıdığımızdan alay ediyor besbelli!" (Baykurt, 2013, s. 156)

“[Siz] Vardığınızda epey olmuş muydu vurulalı?" (Kemal Tahir, 1993, s. 159)

"[Onlar] İç Azap kapısını geçtiklerinde sabah ezanları okunmaya başlamıştı." (Anar, 2006, s. 18)

Aynı şekilde, -DI mI ve -DI -AlI zarf-fiil ekleri bünyesinde görülen şahıs ekleri de aşağıda olduğu gibi bu işlevi gösterir:

"Ağabeyim [Ben] bildim bileli sır küpü ve sükût dondurmasıdır." (Peyami Safa, 2008, s. 23)

“[Sen] Kurnayı çevirdin mi sıcak, [sen] çevirdin mi soğuk!” (Baykurt, 2013, s. 23)

“[O] Güzün vermedi mi, varır tünerim başına." (Baykurt, 2013, s. 18)

“[Biz] Koyunların yanına dört koyun daha aldık mı, bize yeter...” (Baykurt, 2013, s. 21)

“[Onlar] Öfkelendiler mi, kaçmalı." (Peyami Safa, 2008, s. 245)

En belirgin örnekler ise şart-fiille kurulan yan cümlelerde görülmektedir. Şart-fiille kurulan yan cümlelerin yüklemi, işlev olarak fiilimsi özelliği göstermesine karşılık biçimsel olarak çekimli fiil görüntüsündedir. Bu durum, aşağıdaki örneklerde olduğu gibi şart-fiille kurulmuş yan cümlelerde yüklemin şahıs eki almasını ve bu yolla yan cümlenin öznesine de işaret edilmesini sağlar:

"[Ben] Vaktinde yetişemezsem, kefillerimin burunları, kulakları kesilecek..." (Kemal Tahir, 1993, s. 113)

“[Sen] Biraz daha beklersen boynunu vururum!" (Anar, 2006, s. 25)

"[O] Yalan söylerse çok fena." (Peyami Safa, 2008, s. 308)

"Eğer [biz] sayvanın üstüne bir oda yapmazsak, hayatın ucuna yapalım." (Baykurt, 2013, s. 98)

"[Siz] Bunu onlardan hangisine sorarsanız beni gösterir!.." (Kemal Tahir, 1993, s. 103)

“[Onlar] Buna karar verseler koşup bildirmez miydim, Osman Bey!" (Kemal Tahir, 1993, s. 152)

Bu tür örneklerde yan cümlenin öznesi, yüzeysel yapıda açıkça yer almış da olabilir. Söz gelimi, "Bünyamin ve casus delikten dışarı çıktıklarında büyük bir patlama oldu." (Anar, 2006, s. 81), " $\underline{\text { Sen }}$ bana dört metre kaputla bir top 'alaca' aldın mi, yeter..." (Baykurt, 2013, s. 14) ve "Belki bugünün öğrencileri onları seyretselerdi, hafifçe gülümserlerdi." (Atay, 2013, s. 95) örneklerinde yan cümle içinde bir öznenin bulunduğu görülmektedir. Öznenin bu şekilde belirtilmediği yukarıdaki gibi örneklerde ise yan cümlede dile getirilen eylemin gerçekleştiricisine -yani, öznesine- yan cümle yükleminde kalıplaşmış olarak görülebilen iyelik veya şahıs ekleri vasıtasıyla işaret edildiği düşünülebilir.

SEFAD, 2020; (43): 195-220 


\subsection{Yan Cümle ile Cümle Arasındaki Ortak Ögelerle Bildirilen Özne}

Yan cümlenin öznesiyle üst dizimdeki cümlenin öznesi aynı olabilir. Bu durumda, yan cümlenin öznesi yan cümleden eksiltilmiştir ve cümlenin öznesi, aynı zamanda yan cümleden eksiltilen bu özneyi de karşılamaktadır. Söz gelimi, "Dilenci ocağa doğru ilerleyince Büyük Efendi Ebrehe'yi gördü." (Anar, 2006, s. 102) örneğine bakıldığında yan cümlede dile getirilen ilerleme eyleminin de cümlede dile getirilen görme eyleminin de gerçekleştiricisi olarak "dilenci" ögesi öne çıkmaktadır. Benzer şekilde, "Uzun İhsan Efendi bunları söyledikten sonra gömleğinin içinden meşin ciltli bir kitap çıkardı." (Anar, 2006, s. 55) cümlesinde özne olarak bulunan "Uzun İhsan Efendi" ögesi de aynı zamanda belirtilen yan cümlede dile getirilen söyleme eyleminin de faili olarak karşımıza çıkmaktadır.

$\mathrm{Bu}$ kullanım biçiminde özne, cümlenin yüklemini yapısal ve anlamsal olarak tamamlarken yan cümlenin yüklemini sadece anlamsal olarak tamamlar. Bir başka ifadeyle, özne yan cümledeki eylemi kimin veya neyin gerçekleştirdiği hakkında bilgi verirken yan cümleye dâhil olmaz ve bu sebeple de yapısal açıdan yan cümleye değil, yan cümlenin içinde yer aldığı cümleye ait bir öge olarak değerlendirilebilir. Dolayısıyla, burada sözü edilen özne ortaklı̆̆ı, anlamsal bir ortaklıktır. Her türdeki yan cümlenin kullanımında görülebilen bu ortaklık, oldukça sık ve çeşitli örneklerle karşımıza çıkabilmektedir.

Bu bağlamda, ilk olarak isim-fiille kurulu yan cümlelere bakıldığında şu ve benzer örneklerde cümledeki öznenin aynı zamanda yan cümledeki eylemin gerçekleştiricisini de anlamsal olarak karşıladığı düşünülebilir:

“Belki Jale Ogan, Mustafa İnan'ı, Almanya'ya gitmeden önce de beğeniyordu, daha doğrusu seviyordu." (Atay, 2013, s. 111)

“Bünyamin şehzadeyi seyretmeye dalmıştı (...)." (Anar, 2006, s. 48)

"[ㅇ] Yeşil uyku şurubunu avludaki ceviz ağacının dibine dökmeyi ihmal etmedi." (Anar, 2006, s. 51)

"[Sen] Ebrehe'nin hayatını kurtarmakla kendi hayatını da kurtardın." (Anar, 2006, s.

“[미lar] Hınzıryedi'yi küçümsemekle nasıl da büyük bir hata yaptılar." (Anar, 2006, s. 213)

“İnsan sonra 'bu ne işime yarayacak?' diye düşünmekten, uğraştığı konuya aklını veremez olur. (Atay, 2013, s. 35)

Sıfat-fiille kurulu yan cümlelere bakıldığında da cümlenin öznesinin yan cümledeki eylemin de gerçekleştiricisi olarak öne çıktığı şu ve benzeri örneklere rastlanabilir:

"Śamim onun saçlarını okşadıktan sonra karşısına oturdu." (Peyami Safa, 2008, s.

"Renginaz bu sır ticaretinin bedelini peşin isteyecek kadar açıkgöz davrandı." (Peyami Safa, 2008, s. 290)

"[ㅇ] Hareketler arasındaki mana ve zevk farklarını duyamaz bir hale geliyordu." (Peyami Safa, 2008, s. 347)

“[]ㅡ Kaç sayana kadar bulur dereyi?" (Kemal Tahir, 1993, s. 10)

"Ne var ki bekçi, döşeğinde kıvrılmış bir durumda horul horul sürekli uyumakta oluyor[du], (...)" (Anar, 2006, s. 231) 
Cümlenin öznesinin aynı zamanda yan cümlenin öznesine de işaret ettiği bu kullanım biçiminin en belirgin ve yaygın örnekleri ise zarf-fiille kurulu yan cümle türünde aşağıdaki gibi karşımıza çıkmaktadır:

“İhtiyar bunları söylerken yumruğuyla sehpaya vuruyordu.” (Anar, 2006, s.167)

“Çocuk bir köşeye sinerek olacakları izlemeye koyuldu.” (Anar, 2006, s. 65)

"Kalkamadığından oturmakta Ahilik..." (Kemal Tahir, 1993, s. 288)

“Renginaz işini bitirinceye kadar cevap vermedi." (Peyami Safa, 2008, s. 297)

“Kaymakam Bey'imiz bizi topladı̆̆ında ne dedi biliyor musunuz?" (Baykurt, 2013, s. 82)

Şart-fille kurulu yan cümle türünde de cümleyle yan cümle arasinda anlam bakımından görülebilecek özne ortaklığı benzer bir şekilde olup şu ve benzeri örneklerdeki gibi kendini göstermektedir:

“으, bugün gitmese yarın gider şikâta.” (Baykurt, 2013, s. 71)

“Ben aşağıda durursam memurun işini bozarım." (Peyami Safa, 2008, s. 94)

“Biri ne kadar uzaklara gitse senin yanından ayrılmıyor." (Peyami Safa, 2008, s. 151)

“Necile sokağa çıkmışsa, iskarpinlerini bu odada giymedi mi?” (Peyami Safa, 2008, s. 379)

$\mathrm{Bu}$ başlıktaki örneklerde yan cümle bir cümlenin kurgusuna cümle ögesi olarak katılmış da olabilir; cümledeki ögelerden birinin bir parçasını oluşturmuş da olabilir. Burada temel olarak cümlenin öznesinin aynı zamanda yan cümledeki eylemin de faili olarak öne çıkması, her iki şekilde de bir özne ortaklı̆̆ından söz edebilmek için yeterli görünmektedir. Bununla birlikte, yan cümlede özneye işaret eden bir başka biçimbirim veya yapının kullanılmamış olduğuna da ayrıca dikkat edilmelidir.

\subsection{Sıfat Tamlamasının Temel Unsuru ile Bildirilen Özne}

Yan cümlenin bir sıfat tamlamasının kurgusuna yardımcı unsur -yani, sıfat- olarak katılması durumunda özne, sıfat tamlamasının temel unsurunun -yani, ismin- konumuna taşınabilir. Böylece, sıfat tamlamasında nitelendirilen isim, aynı zamanda yan cümledeki kılışın gerçekleştiricisine de anlamsal olarak işaret eder. Söz gelimi, "Çenesiyle \{ayakları dibinde dolaşan / güvercinler ]i gösterdi." (Kemal Tahir, 1993, s. 15) örneğinde belirtilen sifat tamlamasının ilk kısmında "ayakları dibinde dolaşan" şeklinde bir yan cümle görülmektedir. Bu yan cümlede dile getirilen dolaşma eyleminin faili "güvercinler" ögesi ise söz konusu tamlamanın ikinci kısmında bulunmaktadır. Burada "güvercinler" ögesi, yan cümlenin yapısal sınırlarından çıkarak yan cümlenin nitelendirdiği ismin konumuna gelmiştir. Dolayısıyla, söz konusu örnekte "güvercinler" ögesini yapı bakımından artık yan cümlenin öznesi olarak değerlendirmek mümkün olmasa da anlam bakımından ögenin bu işlevini devam ettirdiği düşünülebilir.

Yalnızca sıfat-fiille kurulu yan cümle türünde görülen bu yapıda yan cümle, aşağıdaki örneklerde olduğu gibi başta -An olmak üzere, -AcAk ve -mIş ve daha nadir olarak da -Ar ve -mAz sıfat-fiil ekleriyle kurulmuş olarak karşımıza çıkabilir:

"\{Meyhaneciye iki akçe veren / Kubelik\} damacanasını şarapla doldurdu." (Anar, 2006, s. 29)

“\{Şurada, mangalın başında duran / adam\}1 görüyor musun?” (Anar, 2006, s. 210)

SEFAD, 2020; (43): 195-220 
"Rıhtım \{yedi iklim dört bucaktan gelen / gemiler\}le doluydu." (Anar, 2006, s. 30)

“\{Bu saatte kalkacak / adam $\}$ da tavuk gibi ilk akşamdan tünemeli." (Baykurt, 2013, s. 96)

"\{Bu parayı hemen şimdi verebilecek / on kişi\} ya çıkar, ya çıkmaz içimizden." (Baykurt, 2013, s. 87)

"Yanındaki aksayan da \{dilenmeye çıkmış / esir\}..." (Kemal Tahir, 1993, s. 34)

"Biz \{pala tutmuş / savaşçılar\}1z, (...)" (Kemal Tahir, 1993, s. 91)

“Belki bu batağın üstündeki \{gün görmez /ev\}i sevmiyor.” (Baykurt, 2013, s. 17)

“Fazladan eğitmen aracıdır ki, \{senin gibi rezilleri dümdüz eder / bir araç\}tır. (Kemal Tahir, 1993, s. 123)

Bu konuyla ilgili olarak, çeşitli kaynaklarda da benzer bir yaklaşım ortaya konmuştur. $\mathrm{Bu}$ çerçevede Underhill, yan cümlelerin sıfat işleviyle kendi ögelerinden birini niteleyebileceği, nitelenen bu ögenin özne olup olmadığına göre örneklerin başlıca iki grupta toplanabileceği ve bunlardan öznenin nitelendirildiği birinci tür örneklerde -An ekinin; özne dışındaki bir ögenin nitelendirildiği ikinci tür örneklerde ise -DIk ekinin kullanıldığı yönünde bir görüş ortaya koymuş ve ayrıca, bu iki tür yapı arasında bir fark olarak -DIk ekli örneklerde öznenin ilgi ekini, sıfat-fiilin de şahıs ve sayıya uygun bir iyelik ekini aldığını belirtmiştir (1972, s. 87-88). Buna göre, "Oğlan, mektebe gider." gibi bir önerme "mektebe giden oğlan" şeklinde ifade edildiğinde yan cümlenin kendi öznesini nitelendirdiği -An tipi yapı; "oğlanın gittiği mektep" şeklinde ifade edildiğinde de özne dışındaki bir ögenin nitelendirildiği -DIk tipi yapı ortaya çıkmaktadır (1972, s. 87). Underhill'in bu ayrımına daha sonra pek çok araştırmacı da atıfta bulunmuş ve burada öne çıkan iki tür yapıyı çeşitli açlardan ele alıp değerlendirmişlerdir (Hovdhaugen, 1975, s. 551-552; Hankamer \& Knecht, 1976, s. 123; Dede, 1978, s. 67-77; Csato, 1985, s. 40; Özsoy, 1994, s. 21-22; Kornfilt, 1997, s. 5859; Haig, 1998, s. 150; Erkman Akerson \& Ozil, 1998, s. 120; Karabulut, 2009b, s. 96-97).

$\mathrm{Bu}$ ayrıma göre daha başka örnekleri de değerlendirmek gerekirse söz gelimi "Yumuşacık kuştüyü döşeklerde yatan / bu adam" (Anar, 2006, s. 20) < "Bu adam, yumuşacık kuştüyü döşeklerde yatıyor." gibi bir örnekte yan cümlenin öznesi; "hizmetçinin getirdiği / bardak" (Peyami Safa, 2008, s. 369) < "Hizmetçi bardak/ bardağ getirdi." örneğinde yan cümlenin nesnesi; "Kubelik'in yatıp kalktı̆̆ / tek göz oda" (Anar, 2010, s. 29) < "Kubelik, tek göz odada yatıp kalkıyor." örneğinde de yan cümlenin dolaylı tümleci nitelendirilmiş olmaktadır. Buradaki -An ve -DIk ekleri, ilgili örneklerde en sık görülen sıfatfiil eklerini temsil etmektedir (Erkman Akerson ve Ozil, 1998, s. 120). Ayrıca, -An ekinin yerini -AcAk, -mIş, -Ar ve -mAz sıfat-fiil ekleri ve -DIk ekinin yerini de -AcAk sıfat-fiil eki alabilmektedir.

Bu iki tür yapıdan birincisinde bir yan cümlenin; ikincisinde yan cümleyi kapsayan bir belirtili isim tamlamasının sıfat tamlamasında sıfat olarak yer aldığ dikkat çekmektedir. İlk yapı, doğrudan burada üzerinde durduğumuz konuyla alakalıdır. İkincisi ise özne dışındaki yan cümle ögelerini nitelendirmesi yönüyle konumuz dışında kalıyor gibi görünse de burada sıfatın bir belirtili isim tamlaması niteliğinde olması (hizmetçinin / getirdiği; Kubelik'in / yatıp kalktığı) ve bu belirtili isim tamlamasının yardımcı unsurunun da yan cümlenin öznesine işaret ediyor olması (hizmetçi ve Kubelik), yan cümlede öznenin hangi yollarla ortaya konabileceğiyle ilgili ayrıca üzerinde durulması 
gereken ve bu çalışmada da bir sonraki başlıkta ele alınacak olan farklı bir yapıyı daha göstermektedir.

Buradaki her iki yapı da sonuç itibarıyla Türkçede yan cümlelerle ilgili oldukça dikkat çekici bir hususu ortaya koymakta ve konuyla ilgili öne çıkan görüşler de Türkçede yan cümle konusunun önemli bir yönüne ışık tutmaktadır. Kanaatimizce, örneklerin önemli bir kısmı bu bakış açısıyla açıklanabilir. Bir kısım örnekler için de ayrıca şu hususlara değinilebilir:

Bunlardan ilki, yan cümlenin yükleminin edilgen çatıda olup olmadığıyla ilgilidir. Buna göre, eğer yan cümle yüklemi edilgen çatıdaysa bu, yan cümlenin öznesinin açıça belirtilmediği anlamına gelir. Bu durumda da kendi öznesini nitelendirmesi yönüyle öne çıan ilk gruptaki yan cümlelerin yalnızca özneyi değil özne dişındaki ögeleri de nitelendirebileceğini gösteren şu ve benzeri örnekler karşımıza çıkabilir:

“Benim Hüsnü Ağa'm \{kan alınacak / damar\}ı bilir." (Baykurt, 2013, s. 145)

“Üstünde, \{sayılamayacak kadar çok yama vurulmuş / bir cübbe\} vardı." (Anar, 2010, s. 113)

"Vardapet ertesi günü, \{birer adım aralıklı dügümler atılmış / ölçüm ipi\}ni omuzuna alıp Bünyamin'le birlikte araziye çıktı." (Anar, 2006, s. 73-74)

“\{Gündüzden kazılan / temeller\} dümdüzdü." (Baykurt, 2013, s. 94)

Bu örneklerde şu yapılar dikkat çekmektedir: "kan alınacak / damar < Damardan kan alınacak.", "sayılamayacak kadar çok yama vurulmuş / bir cübbe $<$ Bir cübbeye sayılamayacak kadar çok yama vurulmuş.", "birer adım aralıklı dügümler atılmış / ölçüm ipi < Ölçüm ipine birer adım aralıklı düğümler atılmış.", "gündüzden kazılan / temeller < Temeller gündüzden kazıldı.". Burada aynı yapı içinde özne dışındaki farklı cümle ögelerinin nitelendirildiği görülmekte ve bunu sağlayan husus da -yukarıda da belirtildiği üzere- fiilimsideki edilgenlik eki gibi görünmektedir.

Bu tür örneklerde özne dışındaki ögelerin nitelendiriliyor olması, çeşitli araştırmacılar tarafından da edilgenlik kavramı etrafında açıklanmıştır. Bu bağlamda, Hovdhaugen, söz konusu yapının kullanım yerleri arasında fiilimsinin edilgen olduğu ve öznenin bulunmadığ 1 bu durumdan da söz etmiştir (1975, s. 552). Hankamer ve Knecht, öne sürdükleri öznesizlik ilkesi bağlamında sıfat-fiille kurulu yan cümlede bir öznenin bulunmaması durumunda özne dışındaki ögelerin nitelendirildiği yapının değil, öznenin nitelendirildiği yapının tercih edildiğini belirtmiş ve bir öznesi olmayan edilgen yapıları da bu ilkeyle ilişkilendirmiştir (1976, s. 132). Erkman Akerson ve Ozil ise fiilin geçişlilik özelliğini de göz önünde bulundurmuş ve bu çerçevede, geçişli fiillerin edilgen çatıya dönüştürülmesi durumunda nesnenin özne konumuna taşınarak yan cümle tarafından rahatlıkla nitelendirilebilir hâle geldiğini ve ayrıca, bu durumun yer ve yön bildiren diğer tümleçlerin de nitelendirilebilmesini mümkün kıldığını dile getirmiş (1998, s. 204); geçişli olmayan fiillerin edilgen çatıda olması hâlinde ise öznenin yerini alabilecek bir nesne bulunmadığından işlevleri ne olursa olsun bütün ögelerin -An ekli sıfat-fiil tarafından nitelendirilebildiğini belirtmiştir (1998, s. 205-206).

Erkman Akerson ve Ozil, ayrıca oldurgan çatının bu kullanımı nasıl etkilediği konusunu da sorgulamış ve edilgen örneklerin yanında oldurgan çatılı örneklerde de nitelendirilen unsurun özne dışındaki yan cümle ögeleriyle ilişkili olabileceğini dile

SEFAD, 2020; (43): 195-220 
getirmiştir (1998, s. 191-206). Bu bağlamda, yüklemde hiç çatı ekinin olmaması durumunda nasıl bir cümlenin ortaya çıkabileceğini göz önünde bulundurarak oldurgan çatıya geçişlerde özne dışındaki bazı ögelerin özne konumuna yükselebildiğini ve bu yolla özne dışındaki diğer ögelerin de -An ekli yan cümle tarafından nitelendirilebilir hâle geldiğini belirtmiştir (s. 197-202). Buna göre, söz gelimi "Pek çok serseri bu kentte barınır." gibi bir cümlede yüklem oldurgan çatıya dönüştürülürse cümle de "Bu kent pek çok serseriyi barındırır." şeklini alır ve "pek çok serseriyi barındıran bu kent" yapısında da yan cümle tarafından nitelendirilen "bu kent" unsuru, başlangıçta özne olmadığı hâlde oldurgan çatıyla özne konumuna yükselmiş bir özne olur (s. 199-200). Bu hususla ilgili olarak, “bu kent" unsurunun -öncesinde yer bildirdiği görüşüne katılmakla birlikte- oldurgan çatıya göre biçimlenmiş yapıda artık "barınma" eyleminin gerçekleştiği yere değil, "barındırma" eyleminin gerçekleştiricisine işaret ettiği için doğrudan ve sadece özneyle ilişkilendirilebileceği kanaatindeyiz.

Bu noktada, edilgen ve oldurgan çatılı örnekler arasında bir karşılaştırma da yapılırsa sıfat işlevli yan cümle tarafından nitelendirilen unsurun "bir gün önce kendisine verilen / somun" (Anar, 2006, s. 52) ve "kerpiç kesilen / yer" (Baykurt, 2013, s. 27) gibi edilgen örneklerde eylemi kimin veya neyin gerçekleştirdiği hakkında bilgi vermediği; oysa "tek başına bir orduyu kaçıran / yiğit Alibaz" (Anar, 2006, s. 63) ve "meçhul bir yere doğru at koşturan / Bünyamin" (Anar, 2006, s. 174) gibi oldurgan örneklerde bu özelliği taşıdığ1 görülür. Benzer şekilde, "bütün dişlerini söktüren / iki cavlak" (Kemal Tahir, 1993, s. 36) ve "ev yaptıran / adam" (Baykurt, 2013, s. 58) gibi ettirgen; "Frenkler gibi giyinmiş / bir adam" (Anar, 2006, s. 152) ve "laf altında kalmazlığıyla övünen / Daskalos" (Kemal Tahir, 1993, s. 189) gibi dönüşlü; "çevresinde kedi yavruları gibi oynaşan / güvercinler" (Kemal Tahir, 1993, s. 41) ve "yüksek sesle şakalaşan / Amerikalılar" (Peyami Safa, 2008, s. 193) gibi işteş çatılı örneklerde de nitelendirilen unsurun yan cümlede dile getirilen eylemi kimin veya neyin gerçekleştirdiğini ortaya koyduğu görülmektedir. Dolayısıyla, bu tür örneklerde yan cümle yüklemi -edilgenlik hariç- hangi çatı özelliğini gösterirse göstersin kanaatimizce nitelendirilen ögenin yine yan cümlenin öznesini ifade ettiği düşünülebilir.

Kısacası, bir sıfat tamlamasında sıfat olarak bulunan yan cümle, fiilimside edilgenlik ekinin bulunmaması durumunda kendi öznesini nitelendirebiliyorken fiilimside edilgenlik ekinin kullanılması bu yapı içinde diğer ögelerin de nitelendirilmesine imkân sağlamaktadır. $\mathrm{Bu}$ sebeple, söz konusu kullanım biçimi özne çerçevesinde ele alınırken bu hususiyet doğrultusunda bir sınırlandırmaya gidilip fiilimsinin edilgen çatıda olmaması gerektiği bu noktada belirtilebilir.

İkinci olarak, eğer sıfat olarak kullanılan yan cümlenin kendi yapısal sınırları içinde zaten bir özne mevcutsa bu durumda yan cümlenin nitelendirdiği öge de özne dışındaki bir başka yan cümle ögesi olabilir. Biraz daha nadir görülen bu ikinci husus da şu ve benzeri örneklerde karşımıza çıkmaktadır:

"Şakir Efendi (...) şimdi de \{yılan sokan / yeri\}i yarıyor." (Baykurt, 2013, s. 269)

“(...) \{kervan aşmaz / dağlar\}1 aştım geldim.” (Kemal Tahir, 1993, s. 199)

"\{Kağnı geçecek / yol $\}$ da kalmıyor..." (Baykurt, 2013, s. 148)

"\{Kuzgunlar uçmaz / sarı çoraklar\}a dayandım, medet!" (Kemal Tahir, 1993, s. 303)

Bu örneklerden "yılan sokan / yer < Yılan [o] yeri soktu." ve "kervan aşmaz / dağlar < Kervan dağları aşmaz." yapılarında yan cümle nesnesinin; "kağnı geçecek / yol < Kağnı [o] 
yoldan geçecek." ve "kuzgunlar uçmaz / sarı çoraklar < Kuzgunlar sarı çoraklarda uçmaz." yapılarında ise dolaylı tümlecin nitelendiriliyor olması dikkat çekicidir. Bu örneklerde öznenin (yılan, kervan, kağnı ve kuzgunlar) yan cümlenin yapısal sınırları içinde kalması, nitelendirilen isim konumuna da başka bir yan cümle ögesinin taşınmasını sağlamış gibi görünmektedir.

Bu tür örneklerde görülen özneye kimi araştırmacılar tarafından da diğer yapılarda görülen özne örneklerinden daha farklı semantik özellikler atfedilmiştir. Bu araştırmacılardan Hovdhaugen, özne genellikle insan dışı olduğunda bu yapının kullanıldığını belirtmiştir (1975, s. 552). Hankamer ve Knecht, konuyla ilgili olarak öznenin söz konusu örneklerde belirsiz olduğu görüşünü ortaya koymuştur (1976, s. 133). Erkman Akerson ve Ozil ise bu örneklerde öznenin çoğunlukla cansız varlıklara gönderme yapan, belirlenimi düşük, zayıf bir özne olduğu için sıfat-fiilin sonrasına geçemediğini ve buna bağlı olarak da yer ve yön bildiren tümleçlerin ağırlık kazandığını ifade etmiştir (1998, s. 200-201). Burada öne çıkan görüşler, ölçünlü Türkiye Türkçesindeki örnekler doğrultusunda kabul edilebilir görünmektedir. Bununla birlikte, -An ekinin -DIk ekinin yerini alabildiği bazı tarihî ve çağdaş Türk dilleri ile Anadolu ağızları da göz önünde bulundurulduğunda aynı yapı içinde belirsiz, cansız, insan dışı veya zayıf gibi niteliklerden uzak özne örneklerinin de sıklıkla yer aldığı görülür. Söz gelimi, tarihî Çağatay Türkçesinden “mèn yürügen / yol (benim yürüdüğüm yol)" (Eckmann, 2011, s. 147) gibi bir örnekte; Özbek Türkçesinden “Ådäm äläyhissälåm täblig etgän / tävhid tüşünçäsi (Adem Aleyhisselam'ın tebliğ ettiği tevhit düşüncesi)" (Koraş, 2007, s. 151), Kazak Türkçesinden "men cazğan / xat (benim yazdığım mektup)" (Tamir, 2007, s. 472), Kırgız Türkçesinden "cüz çamaluu adam tegerektegen / han" (yüz kadar adamın çevrelediği han) (Ceritoğlu, 2012, s. 69), KaraçayMalkar Türkçesinden "sen bergen / açha (senin verdiğin para)" (Tavkul, 2007, s. 925) gibi örneklerde karşımıza çıkan özne, herhangi bir cümlede veya yan cümlede bulunabilecek özne örneklerinden farksız görünmektedir. Bu durum, Kars ağzından "herkeş ondan gorhan / bir adam" (Üstüner, 2000, s. 63) ve Muş ağzından "yar dolanan / yerler" (Üstüner, 2000, s. 63) örneklerinde olduğu gibi Anadolu ağızlarında da kendini gösterebilmektedir. Buradaki çeşitliliğin ölçünlü Türkiye Türkçesinde görülmeyişi ise kanaatimizce öznenin söz konusu yapı içinde kendine özgü semantik bir özellik göstermesiyle değil; bu tür örneklerin Türkiye Türkçesinde biraz daha kısıtlı olmasıyla ilgilidir.

\section{4. İsim Tamlamasının Yardımcı Unsuru ile Bildirilen Özne}

Belirtili isim tamlamaları, sırasıyla iyelik eki almış bir isim ile ilgi eki almış bir ismin

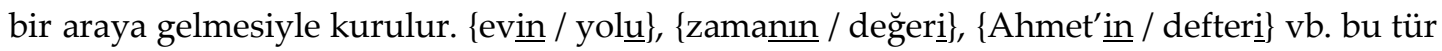
tamlamalarda temel unsur sonda; yardımcı unsur başta bulunur. Birinci isim tamlayanı, ikinci isim tamlananı oluşturur.

$\mathrm{Bu}$ yapılar, yan cümlelerin en sık ve en işlek şekilde kurgusuna katıldığı öbeklerden de biridir ve bu tamlamaların hem temel hem de yardımcı unsuru konumunda bir yan cümle örneği sıklıkla görülebilmektedir. Söz gelimi, \{yere basmanın / emniyetî örneğinde yardımcı unsurun konumunda; \{cismin / şekil değiştirmesi\} örneğinde de temel unsurun konumunda yer almış isim-fiille kurulu yan cümle örnekleri görülmektedir.

İşte yan cümlenin bir belirtili isim tamlamasında temel unsur olarak bulunması -yani, ikinci ismin yerine gelmesi- durumunda özne de yan cümlenin yapısal sınırlarından çıkarak isim tamlamasının yardımcı unsuru konumuna -yani, birinci ismin yerine- gelebilmektedir. $\mathrm{Bu}$ durumda, söz konusu öge isim tamlamasının kurulmasına katkıda bulunurken yan 
cümledeki eylemin failini bildirmeye de anlamsal olarak devam eder. Söz gelimi, "Peki \{Osman Bey'imizin / cenaze günü süslü giyinmesi\} neden ki ola?" (Kemal Tahir, 1993, s. 154) örneğinde görülen belirtili isim tamlamasının ikinci kısmında "cenaze günü süslü giyinme" şeklinde bir yan cümle bulunmaktadır. Bu yan cümledeki giyinme eylemini kimin gerçekleştirdiğini ise isim tamlamasının birinci kısmına taşınmış olan "Osman Bey'imiz" unsuru bildirmektedir.

$\mathrm{Bu}$ yapının örnekleri, isim-fiil ve sıfat-fiille kurulu yan cümle türlerinde görülür. Bunlardan isim-fiille kurulu yan cümlelerde örnekler, çoğu kez -mA ve bazen de -Iş ekiyle kurulmuş olarak aşağıdaki gibi karşımıza çıkar:

“\{Rahiplerin / tüneli keşfetmeleri\} fazla zaman almadı (...)." (Anar, 2006, s. 53)

"\{Birkaç yeniçerinin / onca hasımla başetmesi\} imkânsızdı." (Anar, 2006, s. 80)

"Gözünün ucuyla \{ninesinin / köprüye yaklaşmaşı\}ı adım adım gözlüyor." (Baykurt, 2013, s. 181)

"Uyanık olarak \{[benim] / Simeranya'ya ilk gidişim\}." (Peyami Safa, 2008, s. 20)

"\{Meral' in / büyük bir his mevzuundan bu pakete atlayışı $\}$, bahsin derinleşmesinden korktuğunu gösteriyordu." (Peyami Safa, 2008, s. 274)

Sıfat-fiille kurulan yan cümlelerdeki örnekler de benzer bir nitelik gösterir. Sadece bu örneklerde yan cümle, aşağıda olduğu gibi çoğu kez -DIk veya -AcAk sıfat-fiil ekiyle kurulmuştur:

“O daracık dehlizde $\{$ kim $\underline{i n}$ / kime vurduğ $\underline{u}\}$ belli değildi." (Anar, 2006, s. 80)

“\{Dokumacının / kumaşı iplikten yarattığı \}n biliyoruz." (Anar, 2006, s. 146)

“(...) \{onun / konuları nasıl ilgi çekici bir biçimde sunduğ $\underline{u}$ \} aklıma geldi."(Atay, 2013, s. 20)

"Hem de $\{$ Kaymakamın / iki gün içinde köyleri teftişe çıkacağ $\}$ haberini kattı Muhtar'ın kulağına." (Baykurt, 2013, s. 72)

"\{'Simeranya' nın / ona her şeyi sezdireceği\} şüpheli." (Peyami Safa, 2008, s. 111)

“Kız \{alkolün / onu nereye götüreceğî\}ni düşündü." (Peyami Safa, 2008, s. 270)

Bu tür örneklerden Johanson "-in ekli bir özneyle başlayan isim-fiil önermeleri” olarak söz etmiş (1972, s. 528); Erguvanlı Taylan belirtili isim tamlaması görünümünde olan yan cümlelerde öznenin tamlayan ekini aldığını dile getirmiş (1994, s. 32-33), Haig sıfat-fiilin iyelik bildirdiği örneklerde öznenin de ilgi eki aldığını ifade etmiş (1998, s. 56) ve Erkman Akerson ve Ozil ise belirtili isim tamlaması gibi işleyen bu tür örneklerde öznenin tümüyle yan cümlenin içinde kaldığını belirtmiştir (1998, s. 120-121). Bu değerlendirmelerde ilgi ekini alan unsurun yan cümle içinde bulunan bir öge olarak ele alınması, genel bir kabul gibi görünmektedir.

Bu kabulle ortak bir nokta olarak söz konusu unsurun özneyi ifade ettiği tekrar edilebilir; ancak, bunun yanında öznenin her zaman "çekimsiz" bir öge olduğunu da göz önünde bulundurmak gerekir. Bu doğrultuda, ilgi ekini alan unsurla ilgili yapı ve anlam bakımından bir ayrım yapılacak olursa -(n)In ilgi ekini alan unsurun yapısal olarak bir üst dizimdeki belirtili isim tamlamasının yardımcı unsurunu oluşturduğu; yan cümlenin yüklemini ise sadece anlamsal olarak tamamladığı ifade edilebilir. Buna göre, "Şakir Efendi'nin / yemek yemesi" (Baykurt, 2013, s. 222) yapısı bir belirtili isim tamlamasıdır; ama, 
bir yan cümle değildir. Yan cümle, bu örnekte "yemek yeme" şeklindeki isim-fiil öbeğidir. Eylemin gerçekleştiricisini bildiren "Şakir Efendi" unsuru ise yan cümleye değil, yan cümleyi de kapsayan belirtili isim tamlamasına aittir. Buradaki yapı, "Ayşe' $\underline{\operatorname{nin}}$ / odașı" gibi bir belirtili isim tamlamasında "Ayşe" unsurunun ilgi; "oda" unsurunun da iyelik eki alarak isim tamlamasının tamlayan ve tamlanan olmak üzere iki ayrı birleşenini oluşturmasıyla eş değerdir. Ayrıca, kendi öznesini nitelendiren yan cümle örneklerinde nitelendirilen ismin yapı bakımından artık yan cümlenin değil, sıfat tamlamasının bir unsuru olmasıyla da paraleldir. Yani, nasıl ki "uzak ülkelerden türlü mallar getiren / gemiler" (Anar, 2006, s. 43) örneğinde "gemiler" unsuru yapısal olarak yan cümlenin içinde görülmüyorsa "dayısının / kendisine bir şeyler söylediğĭ" (Anar, 2006, s. 22) örneğinde de "dayısı" unsuru, yine yan cümlenin içinde bulunan bir öge olarak değerlendirilmemelidir. Bu örneklerden ilkinde yan cümlenin öznesini ifade eden "gemiler" unsuru, sıfat tamlamasında tamlanan konumuna taşınmıştır. Benzer bir şekilde, ikinci örnekte de "dayısı" unsuru, belirtili isim tamlamasında tamlayan konumuna taşınmıştır; bundan dolayı da ilgi ekini almıştır.

$\mathrm{Bu}$ yapıdaki örneklerde isim tamlamasının devrik kullanımı da mümkündür. Söz gelimi, “Müsabakayı onun kazandığı kesin gibiydi." (Anar, 2006, s. 52) cümlesinde devrik bir kullanım örneği gözlenmektedir ve bu yapı, "onun / müsabakayı kazandığı”" şeklinde kurallı hâle getirilebilir. Benzer bir şekilde, "İstanbul Teknik Üniversitesi'ne en iyi öğrencilerin girmesi" (Atay, 2013, s. 232) yapısını da "en iyi öğrencilerin / İstanbul Teknik Üniversitesi'ne girmesi" şeklinde kurallı hâle getirmek mümkündür. Bu ve benzeri örneklerin yan cümleden çok yine belirtili isim tamlamasının kullanımıyla ilgili bir özelliği yansıttığı düşünülebilir. Zira, "Tahsilin ticarette yeri yok." (Karahan, 2006, s. 43) ve "Gökyüzüdür zarı beynimizin (Özmen, 2013, s. 60) örneklerinde olduğu gibi ikinci unsuru bir yan cümle niteliği göstermeyen belirtili isim tamlamalarında da benzer kullanım örnekleri görülebilmektedir. Bu tür örnekleri çözümleyebilmek için de öncelikle örneği oluşturan unsurların "isim+ilgi eki / isim+iyelik eki" şeklindeki belirtili isim tamlaması yapısına göre konumlandırılmış biçimini göz önünde bulundurmak gerekir.

$\mathrm{Bu}$ tür örneklerde fiilimsinin edilgen çatıda olmaması gerektiği de yine belirtilmelidir. Edilgenlik, tıpkı yan cümlenin kendi öznesini nitelendirdiği yapıda olduğu gibi bu yapıda da daha farklı örneklerin görülmesine yol açar. Bu örneklerdeki en temel farklılık ise belirtili isim tamlamasının yardımcı unsuru konumuna yan cümlenin öznesi yerine nesnesinin taşınmasıdır. Söz gelimi, "\{Böyle şeylerin / bu köyde görülmesił\}ni istemem Bayram!" (Baykurt, 2013, s. 90) ve "\{Her şeyin / evvelden hazırlandı̆̆ıł $\}$ ı anlıyordum." (Peyami Safa, 2008 , s. 386) gibi örneklerde isim tamlamasının yardımcı unsuru, eyleminin gerçekleştiricisini bildiren özneye değil; "görülen" veya "hazırlanan" şeyin ne olduğunu bildiren nesneye işaret etmektedir.

Bu yapının kullanımıyla ilgili özellikle üzerinde durulması gereken bir diğer nokta ise örneklerin sıfat işleviyle de karşımıza çıkabiliyor olmasıdır. Yan cümlenin daha çok sıfat-fiil ekiyle kurulduğu örneklerde görülen bu kullanım biçimine göre yine ikinci kısmında bir yan cümlenin; birinci kısmında ise bu yan cümlenin öznesinin yer aldığı bir belirtili isim tamlaması söz konusudur. Bu tamlama, bu kez sıfat işleviyle bir sıfat tamlamasının kurgusuna katılır. Bu durumda, nitelendirilen isim de çoğu kez yine yan cümleye ait bir başka ögeyi temsil eder. Söz gelimi, “\{Bünyamin'in /ezandan önce yaktığl\} / mangal” (Anar, 2006, s. 46) sıfat tamlamasına bakıldığında sıfatın böyle bir belirtili isim tamlamasından oluştuğu; nitelendirilen ismin ise yan cümlenin nesnesine işaret ettiği görülmektedir. Daha 
açık bir ifadeyle, burada derin yapı, yüzeysel yapıya bir cümle şeklinde aktarılsaydı "Bünyamin, ezandan önce mangalı yaktı." şeklinde olabilecek bir dizim karşımıza çıkacaktı. Oysa, bu örnekte aynı derin yapı, bir yan cümle şeklinde yüzeysel yapıya aktarılmış ve bu yan cümle, bir belirtili isim tamlamasının kurgusuna temel unsur olarak katılırken öznesini bir üst dizimdeki belirtili isim tamlamasının birinci kısmına; nesnesini de bir sonraki üst dizim olan sıfat tamlamasında nitelendirilen ismin konumuna göndermiştir. Bu yapının sıfat işlevi, "\{Kubelik'in / ürkek ürkek baktığ 1$\}$ / Arap İhsan" (Anar, 2010, s. 33) < "Kubelik, Arap İhsan'a ürkek ürkek bakıyordu." ve "\{benim] / Çöl köylerinden dilendiğim\} / ekmek" (Baykurt, 2013, s. 31) < "Ben, çöl köylerinden ekmek dilendim.", [onun] / su doldurduğu bakır tas (Kemal Tahir, 1993, s. 83) < “O, bakır tasa su doldurdu." gibi daha pek çok örnekte sıklıkla gözlemlenebilir.

Bu yapının sıfat olarak kullanımı, kaynaklarda daha çok bir önceki başlıkta üzerinde durduğumuz yapıyla birlikte ele alınmış ve bu bağlamda, bir önceki örneklerde yan cümlelerin sıfat olarak kendi öznesini nitelendirmesine karşılık, bu yapıdaki örneklerde de nitelendirilen unsurun özne dışındaki yan cümle ögeleri olduğu dile getirilmiştir (bkz. Sifat Tamlamasının Temel Unsuru ile Bildirilen Özne).

Bu başlık altında son olarak bir grup örnekten daha söz edilebilir. Bu örneklerde iyelik ekini fiilimsinin değil, özne dişındaki unsurun aldığı görülür. Söz gelimi, "\{Ayşe'nin / yapacağ 1$\}$ / işler" örneğinde iyelik ekini fiilimsi almıştır. Buna karşın, örneğin "Ayşe'nin / yapacak işleri”" şeklinde olması durumunda bu kez iyelik ekini özne dışındaki unsurun (işler) aldığ1 gözlemlenir. Bu tür örneklerde yan cümle özne dışındaki ögesini nitelendirerek bir sıfat tamlaması (yapacak /işler) oluşturmakta; bu sıfat tamlamasını ise üst dizimde bir belirtili isim tamlaması kapsamaktadır. Dolayısıyla, " $\{$ Ayşsenin / yapacağı $\}$ / işler" yapısı öncelikle bir sıfat tamlaması örneği oluştururken "Ayşe'nin / yapacak işlerị" yapısı da bir belirtili isim tamlaması oluşturmaktadır. Bu açıdan, bu iki tip örneğin esasında yapı bakımından birbirinden tamamen farklı olduğunu belirtmek gerekir. Bununla birlikte, öznenin ifade ediliş biçimi açısından değerlendirildiğinde ikinci tip örneklerde de öznenin bir isim tamlamasının yardımcı unsuruyla belirtildiği görülmektedir. Bu nedenle, bu yapıdaki örneklere de bu başlık altında yer verilebilir.

\section{5. İsim Tamlamasının Temel ve Yardımcı Unsurları ile Bildirilen Özne}

Bu başlıktaki örneklerde yine yan cümlenin yapısal sınırları içinde bulunmayan bir özne söz konusudur ve bu özne, bir belirtili isim tamlaması yapısındadır. Yan cümle ise kendi öznesine işaret eden bu isim tamlamasının ya temel ya da yardımcı unsurunu nitelendirir. Bu nitelendirme işlemi sırasında, söz konusu tamlamanın temel ve yardımcı unsurları arasındaki yapısal bağ ortadan kalkar ve bu unsurlar, artık ayrı yapılar içinde yeni görevler üstlenmiş olarak karşımıza çıkar. Yan cümledeki kılışın gerçekleştirici ise temel ve yardımcı unsurları ayrı yerlerde bulunan bu isim tamlamasının kendini anlamsal olarak göstermesiyle ortaya çıar.

Yan cümle öznesinin böyle bir isim tamlamasiyla bildirilmesi, yan cümlenin bu tamlamanın hangi unsurunu nitelendirdiğgine bağlı olarak iki farklı şekilde gerçekleşir. Buna göre, yan cümle eğer söz konusu isim tamlamasının temel unsurunu -yani, ikinci isminitelendiriyorsa nitelendirdiği bu isimle birlikte bir üst dizimdeki belirtili isim tamlamasının ikinci kısmında bir sıfat tamlaması meydana getirir. Söz gelimi, "\{Haceli'nin / temel kazan işçilerił\}ni gözetliyor." (Baykurt, 2013, s. 69) örneğinde "temel kazan" şeklinde bir yan cümle görülmektedir. Bu yan cümledeki kazma eylemini kimin gerçekleştirdiğine bakıldığında bu 
yan cümleyi çevreleyen "Haceli'nin / işçileri”" şeklinde bir belirtili isim tamlaması karşımıza çıkmaktadır. Burada söz konusu isim tamlaması, yan cümlenin yüklemini anlamsal olarak tamamlarken yan cümle de bu isim tamlamasının kurgusuna "işçiler" unsurunu nitelendiren bir sıfat olarak katılmış ve nitelendirdiği bu unsurla birlikte belirtili isim tamlamasının içinde bir sıfat tamlaması meydana getirmiştir. Çoğunlukla -An sıfat-fiil ekiyle kurulu yan cümlelerde karşımıza çıan bu kullanım biçimi, şu örneklerde de görülmektedir:

"\{Ayrı milletlerin / bir arada okuyan çocukları\} gibiydiler." (Atay, 2013, s. 136)

“(...) \{Kefeli'nin / İspanya'ya hicret eden torunu $\}$ tarafından yadigâr olarak alınıp bir kitabın arasına konacaktı." (Anar, 2006, s. 34)

"\{Necati'nin / salonda kalan kızı\} Nevin yemek odasına doğru yürüdü." (Peyami Safa, 2008, s. 358)

"Sonra, dışardan \{Akış köpeğin / yürek kaldıran sesi\} geldi." (Baykurt, 2013, s. 262)

"\{Necile'nin / heyecan arayan ruhû\}nda böyle bir itirafın koparabileceği fırtınaları tasavvur ettim." (Peyami Safa, 2008, s. 295)

$\mathrm{Bu}$ örneklerde belirtilen yan cümlelerin öznesi olarak "Kefeli'nin / torunü", "ayr1

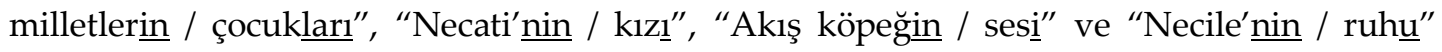
şeklinde birer belirtili isim tamlaması kendini göstermektedir. Yan cümleler ise yukarıda da belirtildiği gibi bu tamlamaların ikinci unsurunu nitelendirmiştir.

Yan cümlenin belirtili isim tamlamasının yardımcı unsurunu -yani, ilk isminitelendirmesi durumunda ise yan cümle bu kez bu yardımcı unsurla birlikte bir sıfat tamlaması meydana getirir ve bu sırada, tamlamanın temel unsuru da yan cümlenin yapısal sınırları içinde kalır. Söz gelimi, "Akrebi sonsuz hızla yol alan / saat" (Anar, 2006, s. 182) örneğinde sıfat tamlamasının sıfatı "Akrebi sonsuz hızla yol alan" şeklinde bir yan cümleden oluşmaktadır. Bu yan cümlede dile getirilen yol alma eylemini kimin veya neyin gerçekleştirdiğine bakıldığında ise "saatin / akrebi" şeklinde bir belirtili isim tamlaması kendini göstermektedir. Bu örnekte, "saatin / akrebị" belirtili isim tamlamasının yardımcı unsuru, yan cümlenin nitelendirdiği ismin konumuna taşınırken temel unsuru da yan cümlenin içinde kalmıştır. Buradaki oluşum da çoğunlukla -An sıfat-fiil ekiyle kurulmuş yan cümlelerin kullanımında karşımıza çıkar ve şu örneklerde de gözlemlenebilir:

“Sonra 'Kuvvet' gelir tabiî; şu \{tanımlanması insanı oldukça üzen / kuvvet\} gelir." (Atay, 2013, s. 210)

"\{Gözleri görmeyen / pembe bir kedi\}, et istiyor." (Baykurt, 2013, s. 113)

“Üstünde \{alı yeşili uçuşan / bir kilim\} dürülü." (Baykurt, 2013, s. 119)

$\mathrm{Bu}$ örneklerde belirtili isim tamlamasının yan cümle içinde kalan temel unsuru (tanımlanması, gözleri ve alı yeşili), yapısal açıdan yan cümlenin yüklemini özne olarak tamamlar. Bununla birlikte, anlamsal boyut da göz önünde bulundurulduğunda eylemin gerçekleştiricisini bildirmesi yönüyle yan cümle yüklemini asıl tamamlayan unsurun parçalanmış ve parçaları ayrı yapılar içinde yeni görevler üstlenmiş bir isim tamlaması olduğu görülür: "kuvvetin / tanımlanmasıı", "pembe bir kedinin / gözlerị" ve "bir kilimin / alı_ yeşilï".

Edilgen çatı, bu gruptaki örnekleri de etkilemektedir. Buna göre, fiilimsinin edilgen olması durumunda isim tamlaması, yan cümlenin öznesi yerine başka bir ögesine işaret edebilir. Söz gelimi, “Aymelek'in / boyunduruk vurulan boynü" (Baykurt, 2013, s. 136) < 
“[Aymelek'in / boynu] $]$ na boyunduruk vuruldu." yapısında yan cümlenin dolaylı tümlecine; "Kuzusu çalınan / koyun" (Baykurt, 2013, s. 187) < "[Koyunun / kuzusu] çalındı." yapısında ise yan cümlenin nesnesine bu yolla işaret edildiği görülmektedir. Bunun dışında, "Kuzusunu kurt kapan / koyun" < "Koyunun kuzusunu kurt kaptı." örneğindeki gibi yan cümlenin içinde bir özne varsa yine söz konusu tamlamanın özne dışındaki ögelere işaret etmesi mümkün olabilmektedir.

Bunun dışında, yan cümlenin çoğunlukla -DIk ekiyle kurulup bir belirtili isim tamlamasında yer aldığı örneklerde de bu yolla özne dışındaki ögelere işaret edilebilir. Söz gelimi, "her çocuğun / bir sayfasını yüksek sesle okuduğ $\underline{u}$ / / kitap" (Anar, 2006, s. 60) örneğinde yan cümle bir belirtili isim tamlamasının içinde temel unsur olarak yer almıştır. $\mathrm{Bu}$ yan cümlenin öznesini (her çocuk) belirtili isim tamlamasının yardımcı unsuru bildirmektedir. Bu yapıya göre burada nitelendirilen "kitap" unsurunun da yan cümlenin özne dışındaki bir ögesine işaret etmesi gerekirdi. Bununla birlikte, söz konusu örnekte özne dışındaki ögeyi "kitap" değil, "kitabıַn / bir sayfaș(nı)" şeklinde bir belirtili isim tamlaması ifade etmektedir. Dolayısıyla, burada da özne dişındaki öge, temel ve yardımcı unsurlarına ayrılmış ve bu ögenin temel unsuru yan cümlenin içinde kalırken yardımcı unsuru da sıfat tamlamasında nitelendirilen ismin konumuna taşınmıştır.

Bu nitelikteki isim tamlamalarının özneye veya özne dışındaki bir ögeye işaret ettiği tüm bu örnekler arasında nasıl bir ayrımın yapılabileceği konusu ise çeşitli kaynaklarda farklı bakış açılarıyla ele alınmıştır. Bu bağlamda, ilk olarak Underhill "üstünde şarap duran masa" ve "üstünde şarabın durduğu masa" vb. şeklinde iki tür yapıya işaret etmiş ve bu yapılardan ilkinde öznenin belirsiz olduğunu; öznenin belirsiz olmaması durumunda ise ikinci tür yapının ortaya çıktığını ifade etmiştir (1972, s. 90). Hankamer ve Knecht ise "Ana Dügüm İlkesi"ni öne sürmüş ve buna göre, büyük bir birimin bir alt parçası nitelenirse sıfatfiilin büyük birime göre seçileceği yönünde bir görüş ortaya koymuştur (1976, s. 127). Bu görüşle paralel olarak, Ardalı isim tamlamasının özneye işaret etmesi durumunda "Ayağı kayan adam" gibi -An ekli örneklerin; başka bir ögeye işaret etmesi durumunda ise “Doktorun ayağını alçıya aldığı adam” gibi öznenin -(n)In ve yüklemin -DIk ekini aldığı örneklerin ortaya çıktığını belirtmiştir (1981, s. 22). Benzer bir şekilde, Erkman Akerson ve Ozil de "çantası kaybolan adam" ve "adamın kaybolan çantası" gibi -An ekli örneklerde parçalanmış belirtili isim tamlamasının yan cümlenin öznesine işaret ettiğini; diğer yan cümle ögeleri için de "Ayşe'nin kedisini beslediği komşu" veya "Ayşe'nin kardeşine kızdığ adam" gibi -DIk ekli örneklerin ortaya çıktığını dile getirmiştir (1998, s. 212-215). Dede, -An ve -DIk ekli örnekler arasındaki ayrımın "Ana Dügüm İlkesi"nden ziyade ilgi ekinin eklenmesiyle ilgili kurallar doğrultusunda yapılabileceği görüşünü öne sürmüştür (1978, s. 67-77). Haig ise -An ekli örneklerde ilgi eki almayan özne için "yarı özne" terimini önermiştir (1998, s. 169-172).

Tüm bu görüşler doğrultusunda belli ve ortak bir sonuca ulaşılamamış olduğu ve aslında buradaki olguyu açılamanın da oldukça zor göründüğü ifade edilebilir. Özellikle de tüm bu karmaşık yapılardan hangisinin ne zaman ve neden tercih edildiği konusunda belli bir kanaate varmak oldukça güç görünmektedir. Bu noktada, sadece karşımızdaki tabloyu ana hatlarıyla betimlemek gerekirse ilk olarak ilgi ve iyelik eklerinin kullanımının yan cümleden çok belirtili isim tamlamasının kurulmasıyla ilgili genel kuralları yansıttığı düşünülebilir. Bunun dışında, parçalarına ayrılmış isim tamlamasının -An ekli örneklerde yan cümlenin öznesini; -DIk ekli örneklerde de özne dışındaki ögelerini karşıladığı -genel 
olarak- ifade edilebilir. Bununla birlikte, -An ekli örneklerde de parçalanmış isim tamlamasının bazı durumlarda özne dışındaki ögelere işaret ettiğini gözlemlemek mümkündür. Kanaatimizce, bu tür örneklerle ilgili olarak -An ekiyle kurulmuş yan cümlenin kendi öznesini niteleyemediği durumları göz önünde bulundurmak gerekir. Yani, bir yan cümle sıfat tamlamasında sıfat olarak bulunursa kendi öznesini niteleyebilir. Bu yapı içinde özne dışındaki bir öge nitelenmek istenirse de ya fiilimsi edilgen çatıya dönüştürülerek öznesiz bir yan cümle oluşturulur ya da özne yan cümlenin içinde tutulur. Böylece, her iki durumda da özne dışındaki bir yan cümle ögesini nitelendirmenin önü açılır. Söz gelimi, "misafirleri gelen / kadın" gibi bir örnekte temel ve yardımcı unsurlarına ayrılmış belirtili isim tamlaması (kadının / misafirlerî) yine yan cümlenin öznesine işaret etmektedir. Bu tür bir örnekte böyle bir tamlama, özne dışındaki bir yan cümle ögesine de işaret edebilir; ancak, bunun için öznenin ya "kuzusu yenen / koyun" örneğindeki gibi edilgen çatı aracılı̆̆ıyla ortadan kaldırılması ya da "kuzusunu kurt yiyen / koyun" örneğindeki gibi yan cümlenin içinde tutulması gerekir.

Ayrıca, bu tür örneklerde isim tamlamasının hangi ögeye işaret ettiğiyle ilgili olarak tamlamanın yan cümle içinde kalan temel unsurunun yan cümlenin yüklemini hangi görevle tamamladığına da bakılabilir. Söz gelimi, "Akrebi sonsuz hızla yol alan / saat" (Anar, 2006, s. 182) örneğinde "saatin / akrebị" tamlaması yol alma eyleminin anlamsal gerçekleştiricisi olarak ortaya çıarken bu tamlamanın bir parçası olan "akrebi" unsuru da yan cümlenin yapısal sınırları içinde özne görevini üstlenmiştir. Eğer böyle bir hususiyet söz konusu değilse bu kez aynı yapı içinde özne dışındaki bir yan cümle ögesinin belirtildiği örnekler karşımıza çıkar. Söz gelimi, "kuzusunu kurt yiyen / koyun” örneğinde ortaya çıkan "koyunun / kuzusu(nu)" tamlamasıyla yan cümlenin öznesi yerine nesnesine işaret edildiği ve aynı zamanda, yan cümlenin yapısal sinırları içinde kalan "kuzusunu" unsurunun da yan cümlenin yüklemine özne değil nesne olarak bağlandığı görülür.

\section{EKSİLTILMIŞ ÖZNE}

Bundan önceki başlıklarda öznenin tıpkı cümlede olduğu gibi yan cümlede de bulunabileceği; eğer yan cümlenin içinde bir özne yoksa da bu kez bir biçimbirim, öge veya yapı aracılığıyla özneye anlamsal olarak işaret edilebileceği belirtildi. Bir kısım örneklerde ise yan cümlede bir özne olmadığı gibi özneye işaret eden herhangi bir unsur da bulunmaz. Söz gelimi, "Ayrıca herkese kendini beğendirmek de pek makbul değildir." (Atay, 2013, s. 269), "Aramızdaki bütün fikir ve zevk münakaşalarını hatırlamak lazımdı." (Peyami Safa, 2008, s. 46) gibi isim-fiille kurulu yan cümlelerde ve "Hiç de ev yapacak zaman değil, (...)!" (Baykurt, 2013, s. 19) ve “Kuzu güdecek yer kalmadı Muhtaaar!" (Baykurt, 2013, s. 88) gibi sıfat-fiille kurulu yan cümlelerde bu tür örnekler görülebilmektedir. Bu örneklerde öznenin eksiltilmiş olduğu düşünülebilir.

Aynı zamanda, söz konusu örnekleri öznenin isim tamlamasının yardımcı unsuruyla bildirildiği yapının eksiltilmiş biçimi olarak düşünmek de mümkündür. Söz gelimi, yukarıdaki örnekler, "insanın / herkese kendini beğendirmesi”, "benim / aramızdaki bütün fikir ve zevk münakaşalarını hatırlamam”, "\{bizị / ev yapacağımız\} zaman” ve "\{çobanın / kuzu güdeceği\} yer" gibi yapıların eksiltilmiş biçimi olarak görülebilir. Diğer taraftan, söz konusu örnekler edilgen yapıdaki örneklerin de yerini alacak şekilde kullanılabilmektedir. Söz gelimi, yine yukarıdaki örneklerden "ev yapacak / zaman" yapısı "ev yapılacak / zaman" yapısını; "kuzu güdecek / yer" yapısı da "kuzu güdülecek / yer" yapısını karşıllyor görünmektedir. Bu grupta sıfat işlevli yan cümlelerin özne dışındaki ögesini nitelendiriyor SEFAD, 2020; (43): 195-220 
olması da öznenin isim tamlamasının yardımcı unsuruyla bildirildiği yapının veya edilgen çatıdaki yan cümle örneklerinin kullanımı göz önünde bulundurularak açıklanabilir.

Bu başlıktaki örnekler, sonuç itibarıyla yan cümlelerin öznesi ifade edilmeden de dile dönüştürülmesinin mümkün olduğunu göstermesi bakımından kayda değerdir. Bu ve benzeri örnekler doğrultusunda öznenin yan cümlede ifade ediliş biçimleri konusuyla ilgili bu çalışma kapsamında sözü edilen tüm hususlara ek olarak derin yapıdaki öznenin yüzeysel yapıda her zaman bir karşılığının olmayabileceği de belirtilebilir.

\section{SONUÇ}

Türkçede fiilimsiler, tıpkı çekimli fiiller gibi özne, nesne, dolaylı tümleç ve zarf tümleci gibi cümleye özgü ögeleri yönetebilme özelliği gösterir. Bu tür ögelerin fiilimsilere bağlanmasıyla ortaya çıkan fiilimsi öbekleri de bir tür sözcük öbeği olmanın yanında bir yüklem ile ona bağlı özne, nesne ve tümleç gibi tamamlayıcı ögelerden müteşekkil cümlesel bir dizimi ifade eder. Bundan dolayı, cümleyle ortak bir özellik gösteren söz konusu yapılar, yönetici ögesinin -yani, fiilimsinin- çekimsiz olması sebebiyle de cümleden ayrılır. Bu iki temel husus doğrultusunda da her fiilimsi ve fiilimsi öbeği, aynı zamanda bir yan cümle olarak değerlendirilebilir.

Dildeki kullanım alanına bakıldığında -yapısı gereği- cümle gibi bağımsız bir şekilde kullanılamayan yan cümlelerin ya bir cümlenin ya da bir sözcük öbeğinin kurgusuna katıldığı ve bu yolla, basit bir cümlenin ifade edebileceğinden çok daha geniş bir anlam alanının tek bir cümle hâlinde yüzeysel yapıda somutlaştırılabilmesini sağladığı görülür. Bu işlevini yerine getirirken de kurgusuna katıldığı cümleyle veya sözcük öbeğiyle birtakım yapısal ve anlamsal bağlar kurarak bütünleşir. Bu bütünleşmenin sağlanmasında yan cümle ögelerinin de önemli görevler üstlendiği görülür.

Bu çerçevede, bir yan cümle ögesi olarak özne incelendiğinde öncelikle bu ögenin tıpkı cümlede yüklemi tamamladığı gibi yan cümlede de yüklemi oluşturan fiilimsiyi tamamladığı ve bu yönüyle, cümledeki kullanımıyla aynı nitelikleri gösterdiği gözlemlenir. Öznenin yan cümleyle üst dizim arasında nasıl ve ne şekilde bağlar kurabileceği sorgulandığında ise söz konusu ögenin genellikle üst dizime ait belli bir konuma taşınmış olduğu görülür. Bu durumda, yan cümlenin içinde bir özne bulunmaz ve yan cümlede dile getirilen eylemi kimin veya neyin gerçekleştirdiği bilgisi, bazen ortak öge kullanımıyla bazen de isim veya sıfat tamlaması gibi belli bir yapının belli bir unsuruyla verilir. Bunun dışında, bazı yan cümle türlerinde kalıplaşmış şahıs veya iyelik ekleriyle de öznenin ifadesi mümkün olabilmektedir. Tüm bu örneklerin ortak noktası ise öznelerinin yan cümleye özgü bir yolla anlamsal olarak ifade ediliyor olmasıdır. Bu çalışmada özneyi bu şekilde belirtmek için takip edilen temel olarak beş farklı yoldan söz edilmiştir. Karşımıza çıkabilecek yeni örnekler doğrultusunda öznenin daha farklı şekillerde belirtildiği yapı ve kullanımlardan da söz etmek mümkündür. Ayrıca, yan cümle içinde doğrudan belirtilmemiş diğer ögeler için de aynı veya benzer durumların geçerli olabileceği göz önünde bulundurulmalıdır.

Son söz olarak yan cümlelerin Türkçenin cümle yapısıyla ilgili oldukça önemli veriler sunan yapılar olduğu belirtilebilir. Bu verilerin bütünüyle bir araya getirilerek konuyla ilgili çok daha kapsamlı bir birikimin oluşturulabilmesi için de söz konusu yapıların hem kendi sınırları içinde gösterdiği cümlesel özellikleri hem de kurgusuna katıldığı üst dizimle kurduğu ilgi ve bağıntıları yönüyle daha çok ele alınıp incelenmesi önem arz etmektedir. 


\section{SUMMARY}

Subordinate clause is a structure whose predicate is a nonfinite verb. The most remarkable feature of this structure is that it has elements such as the subject, object and complement of place or adverb just like a sentence and therefore, has a syntagmatic value similar to a sentence.

In this study, the subject, which is one of the elements that can be seen in a subordinate clause, has been handled and has been researched in terms of how the subject has been used in this structure.

According to this research, it can be stated that the subject is used in the subordinate clause, just as it is used in a sentence. In this case, the subject appears in the subordinate clause, which it is dependent on the nonfinite verb both structurally and semantically. On the other hand, the subject may not always be found in the subordinate clause. In this case, one of the certain ways are followed to express the subject systematically.

Firstly, the subject can be marked with a morpheme. This morpheme is mostly a formulaic personal or possessive suffix.

Secondly, there is a common subject between the subordinate clause and the main clause. In this case, there is no subject within the grammatical boundaries of the subordinate clause and the subject of the main clause that also indicates its subject semantically.

Thirdly, the subordinate clause is included in an adjective group as an adjective. The subject is subtracted from subordinate clause and is moved to the position of the head noun. In this way, the head noun of the adjective group expresses the subject of the subordinate clause. In such examples, there is now only a semantic link between the subject and the nonfinite verb.

Fourthly, the subordinate clause is included in a determined noun group as second component. The subject is subtracted from subordinate clause again and is this time moved to the position of first component of the noun group. So, the subject is expressesed by this component. Here, it can't also be said that the subject is dependent on the nonfinite verb structurally. There is only a semantic link.

Fifthly, subject subtracted from the subordinate clause is always a structure of a noun group and it's broken into pieces around the the subordinate clause. Meanwhile, the clause qualifies either the first or second component of this noun group with the adjective function. In such examples, the subject is expressed semantically by a noun group whose components have taken on new tasks within different structures.

Other than these, it is possible that there is not always a sign of the subject of the subordinate clause in the surface structure.

It should also be noted that there are many details regarding these substances which are briefly summarized above. As attempted in this study, determining all these details with different examples is very important in order to understand the structure and usage features of the subordinate clause in Turkish. 


\section{KAYNAKÇA}

Aksan, D. (2005). Her yönüyle dil ana çizgileriyle dilbilim. Ankara: TDK Yayınları.

Aktan, B. (2009). Türkiye Türkçesinin söz dizimi. Ankara: Gazi Kitabevi.

Ardalı, R. (1981). Çağdaş dilbilim açısından ortaçlar. SEFAD, (1), 17-25.

Atabay, N., Özel, S. \& Çam, A. (1981). Türkiye Türkçesinin sözdizimi. Ankara: TDK Yayınları.

Banguoğlu, T. (1974). Türkçenin grameri. Ankara: TDK Yayınları.

Benzer, A (2010). -sA ekinin işlevleri ve dilek-şart ayrımı. Türkiyat Araştırmaları Dergisi, (28), $131-140$.

Bilgegil, K. (1963). Eğitim enstitüleri için Türkçe dilbilgisi edebiyat bilgi ve teorilerine giriş faksül 1. Ankara: Güzel İstanbul Matbaası.

Bilgin, M. (2002). Anlamdan anlatıma Türkçemiz. Ankara: Başbakanlık Basımevi.

Bozkurt, F. (2010). Türkçenin abc'si. İstanbul: Say Yayınları.

Böler, T. (2019). Türkiye Türkçesi söz dizimi. İstanbul: Kesit Yayınları.

Burdurlu, İ. (1967). Uygulamalı cümle çözümlemeleri. İzmir: Karınca Matbaacılık.

Cemiloğlu, İ. (2001). Dede Korkut hikâyeleri üzerinde söz dizimi bakımından bir inceleme. Ankara: TDK Yayınları.

Ceritoğlu, M. (2007). Kırgız Türkçesinin söz dizimi. Ankara: Kesit Yayınları.

Csato, E. A. (1985). A syntactic analysis of participle constructions in modern Turkish. O. F. Sertkaya \& C. E. Alışık (Haz.), 23-28 Eylül 1985 V. Milletlerarası Türkoloji Kongresi Tebliğler 1 içinde (s. 39-56). İstanbul: Edebiyat Fakültesi Basımevi.

Daşdemir, M. (2014). Oklama yöntemiyle yapısal-işlevsel söz dizimi. Erzurum: Eser Basım Yayın.

Dede, M. (1978). Why should Turkish relativization distinguish between subject and nonsubject head nouns?. Berkeley Linguistics Society, BLS 4, 67-77.

Delice, İ. (2004). Cümle öğelerinin sınıflandırılması ve cümlenin temel öğeleri. Türk Dili ve Edebiyatı Makaleleri, (4), 127-170.

Delice, İ. (2007). Türkçe sözdizimi. İstanbul: Kitabevi.

Delice, İ. (2012). Cümle nasıl tanımlanmalıdır?. Turkish Studies, 7/1, 37-40.

Demir, N. \& Yılmaz, E. (2003). Türk dili el kitabı. Ankara: Grafiker Yayınları.

Deniz Yılmaz, Ö. (2009). Türkiye Türkçesinde eylemsi. Ankara: TDK Yayınları.

Develi, H. (1995). -sA eki nedir? Kip mi, zarf-fiil mi?. İlmî Araştırmalar: Dil Edebiyat, Tarih Incelemeleri, (1), 91-94.

Dizdaroğlu, H. (1976). Tümcebilgisi. Ankara: TDK Yayınları.

Eckmann, J. (2011). Harezm, Kıpçak ve Çağatay Türkçesi üzerine araştırmalar, O. F. Sertkaya (Yay. haz.). Ankara: TDK Yayınları.

Ediskun, H. (1963). Yeni Türk dilbilgisi. İstanbul: Remzi Kitabevi.

Emre, A. C. (1945). Türk dilbilgisi Türkçenin bugünkü ve geçmişteki gelişmeleri üzerine gramer denemesi. İstanbul: Cumhuriyet Matbaas1.

Ergin, M. (1962). Türk dil bilgisi. İstanbul: İstanbul Matbaası.

Erguvanlı Taylan, E. (1994). Yantümcelerde tamlayan ekinin işlevi üzerine. Dilbilim Araştırmalan Dergisi, 5, 31-41. 
Erkman Akerson, F. \& Ozil, Ş. (1998). Türkçede niteleme sıfat işlevli yan tümceler. İstanbul: Simurg Yayınları.

Erkul, R. (2007). Cümle metin bilgisi. Ankara: Anı Yayıncllı.

Gencan, T. N. (1966). Dilbilgisi. İstanbul: Ahmet Sait Basımevi.

Gülsevin, G. (1990). Türkçede -sA şart gerundiumu üzerine. Türk Dili Aylık Dil Dergisi, (467), 276-279.

Haig, G. (1998). Relative constructions in Turkish, Wiesbaden: Harrassowitz Verlag.

Hankamer, J. \& Knecht, L. (1976). The role of subject/non-subject distinction in determining the choice of relative clause participle in Turkish. Harvard Studies in Syntax and Semantics, II, 123-135.

Hatiboğlu, V. (1972). Türkçenin sözdizimi. Ankara: TDK Yayınları.

Hovdhaugen, E. (1975). Relative clauses in Turkish. Bilimsel Bildiriler 1972 içinde (s. 551-554). Ankara: TDK Yayınları.

İlhan, N. (2009). Birleşik cümle kuruluşunda şart cümlesi ya da zarf grubu. H. Develi (Ed.), 27-28 Ağustos 2007 Uluslararası Türk Dili ve Edebiyatı Kongresi (UTEK 2007) içinde (s. 253260). İstanbul: G.M. Matbaacilık.

Johanson, L. (1972). Fiilimsi önermelerin görevleri üzerine. Bilimsel Bildiriler 1972 içinde (s. 525-529). Ankara: Türk Dil Kurumu Yayınları.

Karabulut, F. (2009a). Ad Öbeği Taşınımı ve Boşluk Kuramı Bağlamında Fiilimsili Yapıların Adlandırılması ve Sınıflandırılması Meselesi. 27-28 A ̈̆ustos 2007 Uluslararası Türk Dili ve Edebiyatı Kongresi (UTEK 2007) içinde (s. 261-298). İstanbul: G.M. Matbaacıllk.

Karabulut, F. (2009b). Köktürkçenin sıfat fiilli yapı tipolojisi. Bilig, (48), 91-118.

Karahan, L. (1994a). Türkçede birleşik cümle problemi. Türk Dili Dil ve Edebiyat Dergisi, (505), 19-23.

Karahan, L. (1994b). -sa / -se eki hakkında. Türk Dili Dil ve Edebiyat Dergisi, (516), 471-474.

Karahan, L. (2000). Yapı bakımından cümle sınıflandırmaları üzerine. Türk Dili Dil ve Edebiyat Dergisi, (583), 16-23.

Karaörs, M. (2005). Türkiye Türkçesi ile Kazak Türkçesinin birleşik cümle bakımından karşılaştırılması. Türk Lehçelerinde Karşılaştırmalı Şekil ve Cümle Bilgisi (Cümle Tahlilleri), Ankara: Akçă̆ Yayınları.

Koç, N. (1990). Yeni dilbilgisi. İstanbul: İnkılâp Kitabevi.

Koraş, H. (2007). Özbek Türkçesinde -gän/-kän, -ķän sıfat-fiil eki, yapım ekiyle genişlemiş gänlig/-känlig, -ḳänlig şekli ve Türkiye Türkçesinde kullanışlara karşılık gelen şekiller. Türklük Bilimi Araştırmaları, (21), 143-167.

Korkmaz, Z. (1997). Batı dilleri ve Türk dili grameri üzerindeki etkileri. TDAY Belleten, 45(1997), 48-54.

Korkmaz, Z. (2007a). Gramer terimleri sözlü̈̆̈̈̈. Ankara: TDK Yayınları.

Korkmaz, Z. (2007b). Türkiye Türkçesi grameri şekil bilgisi. Ankara: TDK Yayınları.

Kornfilt, J. (1997). Turkish. Londra ve New York: Routledge.

Kükey, M. (1975). Uygulamalı örneklerle Türkçenin sözdizimi. Ankara: Kardeş Matbaası.

Kültüral, Z. (2018). Türkiye Türkçesi cümle bilgisi. Konya: Palet Yayınları.

SEFAD, 2020; (43): 195-220 
Mansuroğlu, M. (1955). Türkçede cümle çeşitleri ve bağlayıcıları. TDAY Belleten, 3, 59-71.

Mehmedoğlu, A. (2005). Türkiye Türkçesinde birleşik cümle üzerine. Sakarya: Sakarya Üniversitesi Yayınları.

Özkan, A., Toker, M. \& Aşçı U. D. (2016). Türkiye Türkçesi söz dizimi. Konya: Palet Yayınları.

Özkan, M. \& Sevinçli, V. (2011). Türkiye Türkçesi söz dizimi. İstanbul: Akademik Kitaplar.

Özmen, M. (2013). Türkçenin sözdizimi. Adana: Karahan Kitabevi.

Özsoy, S. (1994). Türkçe'de ortaç yapısı. Dilbilim Araştırmaları Dergisi, 5, 21-30.

Sağlam, S. (1977). Türkçenin sözdizimi örneklerle tümce çözümlemeleri. Diyarbakır.

Savran, H. (1999). Birleşik cümle üzerine. Türk Dili Dil ve Edebiyat Dergisi, (568), 325-330.

Şimşek, R. (1987). Örneklerle Türkçe sözdizimi tümceler-belirtme öbekleri-çözümleme. Trabzon: Kuzey Gazetecilik Matbaacilık.

Tamir, F. (2007). Kazak Türkçesi. A. B. Ercilasun (Ed.), Türk Lehçeleri Grameri içinde (s. 429480) Ankara: Akçă̆ Yayınları.

Tavkul, U. (2007). Karaçay-Malkar Türkçesi. A. B. Ercilasun (Ed.), Türk Lehçeleri Grameri içinde (s. 883-938) Ankara: Akçağ Yayınları.

Topaloğlu, A. (1989). Dil bilgisi terimleri sözlüğ̈̈. İstanbul: Ötüken Neşriyat.

Toparl, R., Karakaş, T. \& Vural, H. (1995). Türk dili. Sivas: Seyran Yayınları.

Turan, Z. (1999). Cümlenin yapısı ile ilişkilendirilen 'basit' ve 'birleşik' kavramları üzerine. Türklük Bilimi Araştırmaları, (8), 299-311.

Underhill, R. (1972). Turkish participles. Linguistic Inquiry, 3(1), 87-99.

Uzun, N. E. (1998). Dilbilgisinin temel kavramları Türkçe üzerine tartışmalar. Ankara.

Uzun, N. E. (2000). Anaçizgileriyle evrensel dilbilgisi ve Türkçe. İstanbul: Multilingual.

Üçok, N. (1947). Genel dilbilim (Lengüistik). Ankara: DTCF Yayınları.

Üstüner, A. (2000). Anadolu ağızlarında sıfat-fiil ekleri. Ankara: TDK Yayınları.

Üstünova, K. (2010). Yüzey yapı-derin yapı kavramları üzerine. Turkish Studies, 5/4, 697-704.

Yücel, B. (2000). Türkiye Türkçesinde zarf-fiil eklerinin yapı bakımından sınıflandırılması üzerine. Türklük Bilimi Araştırmaları, (9), 75-114.

Zülfikar, H. (1995). Girişik cümle sorunu. Türk Dili Dil ve Edebiyat Dergisi, (522), 643-648.

\section{Ek: Örnek Taranan Kaynaklar}

Anar, İ. O. (2010). Puslu kıtalar atlası (38. bs). İstanbul: İletişim Yayınları.

Atay, O. (2013). Bir bilim adamının romanı (40. bs.). İstanbul: İletişim Yayınları.

Baykurt, F. (2013). Yılanların öcü (21. bs). İstanbul: Literatür Yayıncılık.

Kemal Tahir. (1993). Devlet ana (10. bs.). İstanbul: Tekin Yayınevi.

Peyami Safa. (2008). Yalnızız (16. bs). İstanbul: Alkım Yayınevi. 